\title{
LEVEL II SCOUR ANALYSIS FOR BRIDGE 13 (BRAITH00150013) on TOWN HIGHWAY 15, crossing the THIRD BRANCH WHITE RIVER, BRAINTREE, VERMONT
}

Open-File Report 98-290

Prepared in cooperation with

VERMONT AGENCY OF TRANSPORTATION

and

FEDERAL HIGHWAY ADMINISTRATION

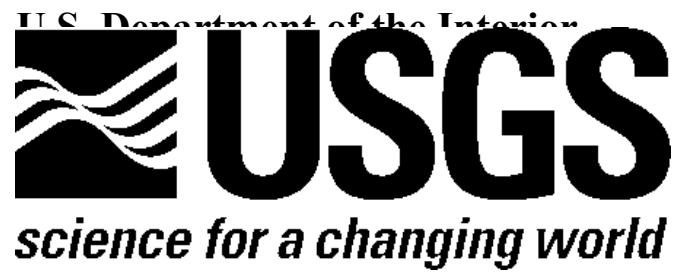




\section{LEVEL II SCOUR ANALYSIS FOR BRIDGE 13 (BRAITH00150013) on TOWN HIGHWAY 15, crossing the THIRD BRANCH WHITE RIVER, BRAINTREE, VERMONT}

By RONDA L. BURNS and MATTHEW A. WEBER

U.S. Geological Survey Open-File Report 98-290

Prepared in cooperation with

VERMONT AGENCY OF TRANSPORTATION

and

FEDERAL HIGHWAY ADMINISTRATION 


\title{
U.S. DEPARTMENT OF THE INTERIOR BRUCE BABBITT, Secretary
}

\author{
U.S. GEOLOGICAL SURVEY
}

Thomas J. Casadevall, Acting Director

For additional information write to:

District Chief

U.S. Geological Survey 361 Commerce Way

Pembroke, NH 03275-3718
Copies of this report may be purchased from:

U.S. Geological Survey

Branch of Information Services

Open-File Reports Unit

Box 25286

Denver, CO 80225-0286 


\section{CONTENTS}

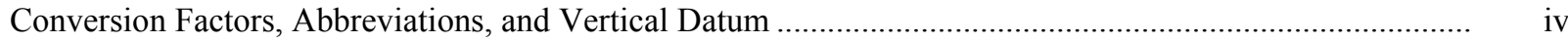

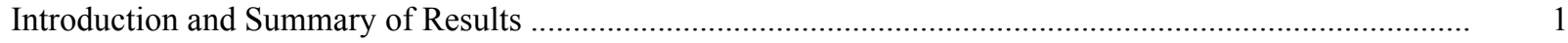

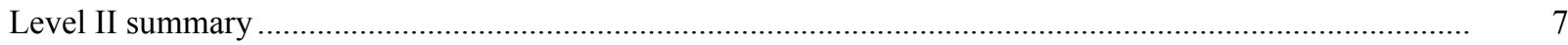

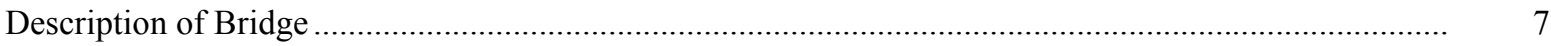

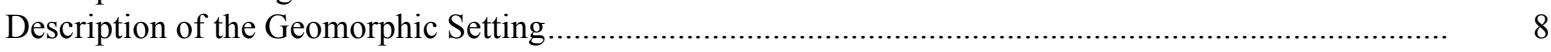

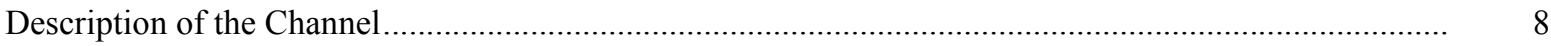

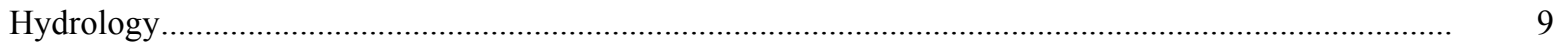

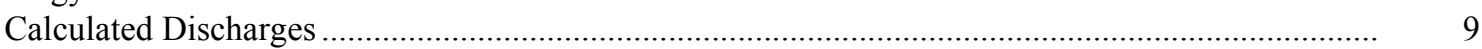

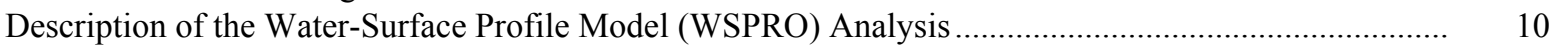

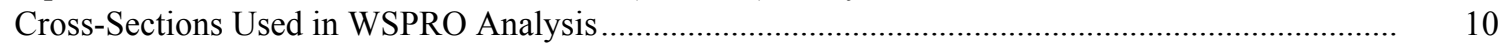

Data and Assumptions Used in WSPRO Model ........................................................................ 11

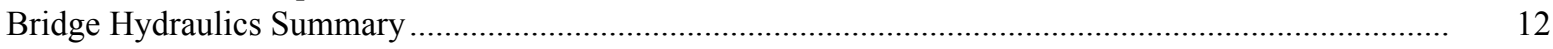

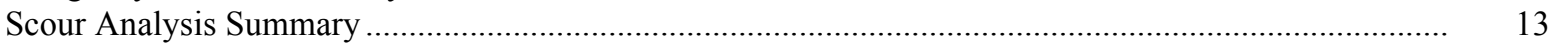

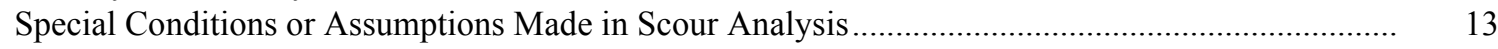

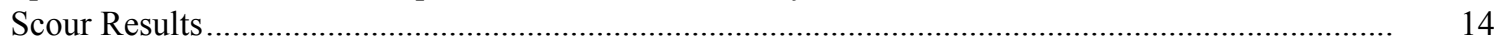

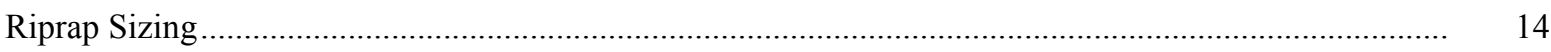

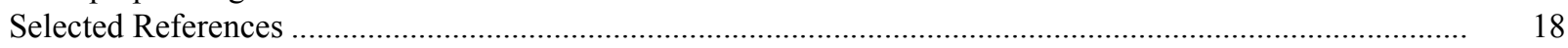

Appendices:

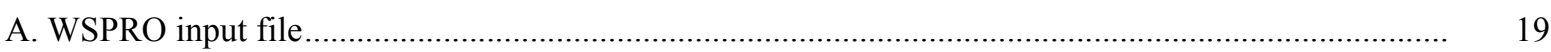

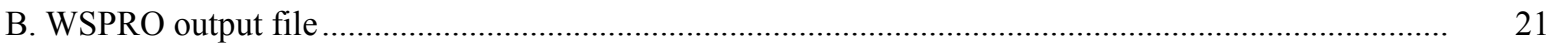

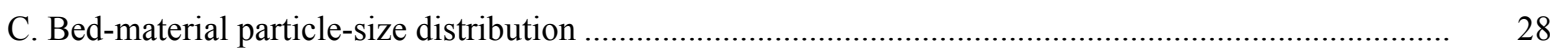

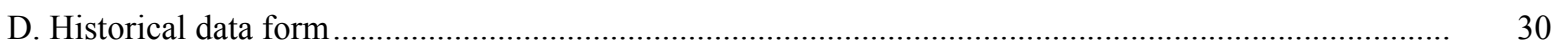

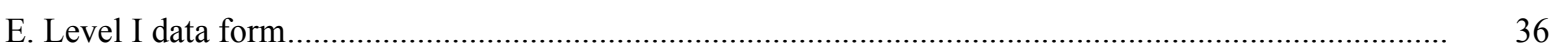

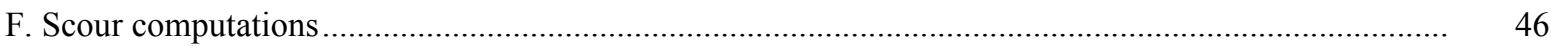

\section{FIGURES}

1. Map showing location of study area on USGS 1:24,000 scale map

2. Map showing location of study area on Vermont Agency of Transportation town highway map ...

3. Structure BRAITH00150013 viewed from upstream (October 21, 1994).....

4. Downstream channel viewed from structure BRAITH00150013 (October 21, 1994)

5. Upstream channel viewed from structure BRAITH00150013 (October 21, 1994)

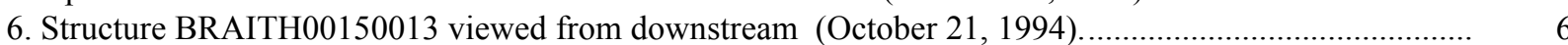

7. Water-surface profiles for the 100- and 500-year discharges at structure

BRAITH00150013 on Town Highway 15, crossing the Third Branch White River,

Braintree, Vermont.

8. Scour elevations for the 100- and 500-year discharges at structure

BRAITH00150013 on Town Highway 15, crossing the Third Branch White River,

Braintree, Vermont.

\section{TABLES}

1. Remaining footing/pile depth at abutments for the 100-year discharge at structure

BRAITH00150013 on Town Highway 15, crossing the Third Branch White River,

Braintree, Vermont.

2. Remaining footing/pile depth at abutments for the 500-year discharge at structure

BRAITH00150013 on Town Highway 15, crossing the Third Branch White River,

Braintree, Vermont 


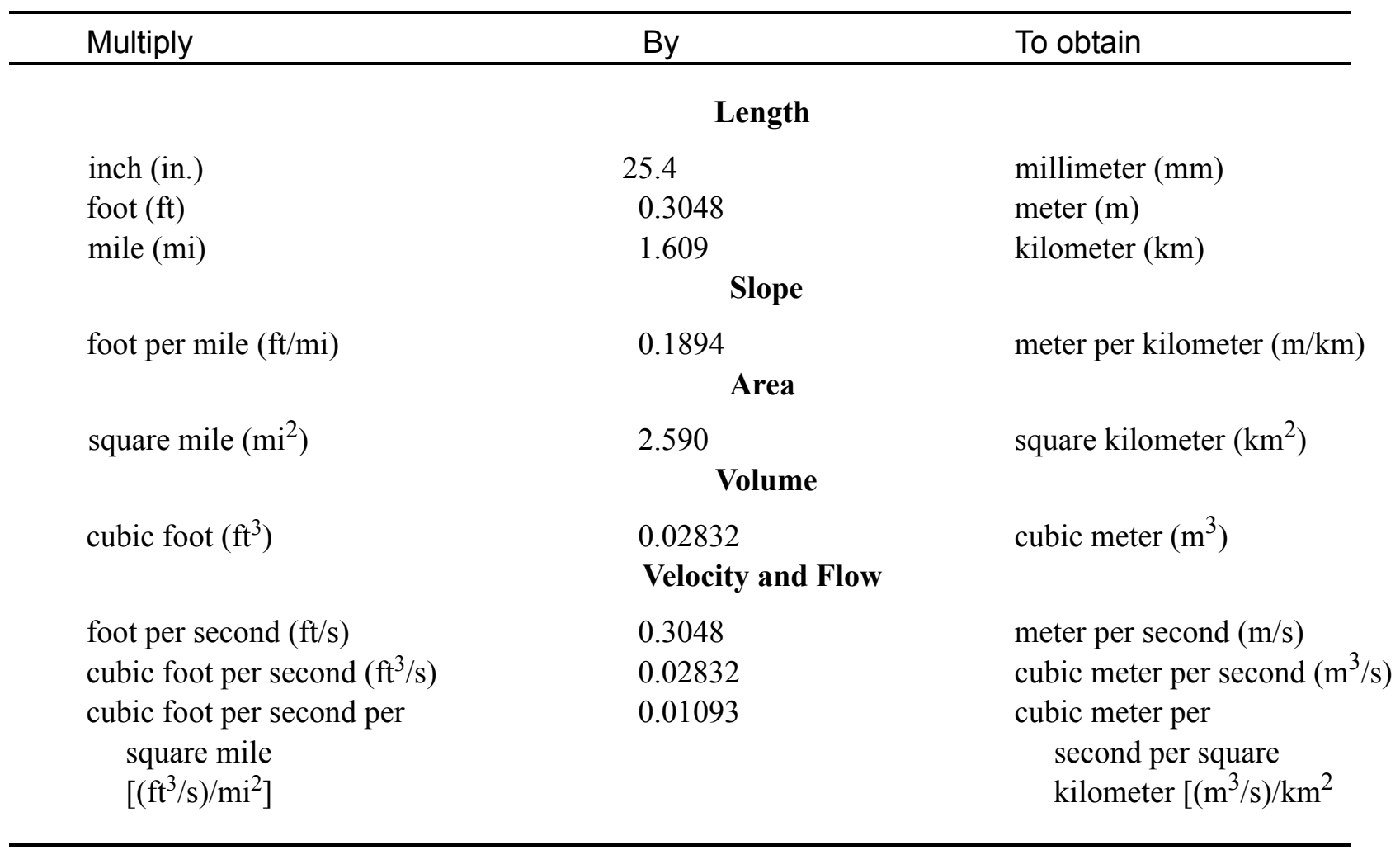

\section{OTHER ABBREVIATIONS}

$\begin{array}{lrlr}\mathrm{BF} & \text { bank full } & \text { LWW } & \text { left wingwall } \\ \mathrm{cfs} & \text { cubic feet per second } & \text { Max } & \text { maximum } \\ \mathrm{D}_{50} & \text { median diameter of bed material } & \text { MC } & \text { main channel } \\ \mathrm{DS} & \text { downstream } & \text { RAB } & \text { right abutment } \\ \mathrm{elev} & \text { elevation } & \text { RABUT } & \text { face of right abutment } \\ \mathrm{f} / \mathrm{p} & \text { flood plain } & \text { RB } & \text { right bank } \\ \mathrm{ft} & \text { square feet } & \text { ROB } & \text { right overbank } \\ \mathrm{ft} / \mathrm{ft} & \text { feet per foot } & \text { RWW } & \text { right wingwall } \\ \mathrm{FEMA} & \text { Federal Emergency Management Agency } & \text { TH } & \text { town highway } \\ \mathrm{FHWA} & \text { Federal Highway Administration } & \text { UB } & \text { under bridge } \\ \mathrm{JCT} & \text { junction } & \text { US } & \text { upstream } \\ \text { LAB } & \text { left abutment } & \text { USGS } & \text { United States Geological Survey } \\ \text { LABUT } & \text { face of left abutment } & \text { VTAOT } & \text { Vermont Agency of Transportation } \\ \text { LB } & \text { left bank } & \text { WSPRO } & \text { water-surface profile model } \\ \text { LOB } & \text { left overbank } & \text { yr } & \text { year }\end{array}$

In this report, the words "right" and "left" refer to directions that would be reported by an observer facing downstream. Sea level: In this report, "sea level" refers to the National Geodetic Vertical Datum of 1929-- a geodetic datum derived from a general adjustment of the first-order level nets of the United States and Canada, formerly called Sea Level Datum of 1929.

In the appendices, the above abbreviations may be combined. For example, USLB would represent upstream left bank. 


\title{
LEVEL II SCOUR ANALYSIS FOR BRIDGE 13 (BRAITH00150013) ON TOWN HIGHWAY 15, CROSSING THE THIRD BRANCH WHITE RIVER, BRAINTREE, VERMONT
}

\author{
By Ronda L. Burns and Matthew A. Weber
}

\section{INTRODUCTION AND SUMMARY OF RESULTS}

This report provides the results of a detailed Level II analysis of scour potential at structure BRAITH00150013 on Town Highway 15 crossing the Third Branch White River, Braintree, Vermont (figures 1-8). A Level II study is a basic engineering analysis of the site, including a quantitative analysis of stream stability and scour (FHWA, 1993). Results of a Level I scour investigation also are included in appendix E of this report. A Level I investigation provides a qualitative geomorphic characterization of the study site. Information on the bridge, gleaned from Vermont Agency of Transportation (VTAOT) files, was compiled prior to conducting Level I and Level II analyses and is found in appendix D.

The site is in the Green Mountain section of the New England physiographic province in central Vermont. The $28.6-\mathrm{mi}^{2}$ drainage area is in a predominantly rural and forested basin. In the vicinity of the study site, the surface cover is shrub and brushland.

In the study area, the Third Branch White River has a sinuous channel with a slope of approximately $0.002 \mathrm{ft} / \mathrm{ft}$, an average channel top width of $60 \mathrm{ft}$ and an average bank height of $6 \mathrm{ft}$. The channel bed material ranges from sand to boulders with a median grain size $\left(\mathrm{D}_{50}\right)$ of $77.1 \mathrm{~mm}(0.253 \mathrm{ft})$. The geomorphic assessment at the time of the Level I and Level II site visit on October 20-21, 1994, indicated that the reach was stable.

The Town Highway 15 crossing of the Third Branch White River is a 44-ft-long, one-lane bridge consisting of one 35-foot steel-beam span (Vermont Agency of Transportation, written communication, August 24, 1994). The opening length of the structure parallel to the bridge face is $34.4 \mathrm{ft}$. The bridge is supported by vertical, concrete abutments with wingwalls. The channel is skewed approximately 25 degrees to the opening and the computed opening-skew-to-roadway is 25 degrees. 
A scour hole $1.0 \mathrm{ft}$ deeper than the mean thalweg depth was observed in the upstream channel and under the bridge during the Level I assessment. Downstream of the bridge, the scour hole was $4.0 \mathrm{ft}$ deeper than the mean thalweg depth. Scour protection measures at the site included type-2 stone fill (less than 36 inches diameter) along the upstream left and right banks, the upstream left wingwall, the downstream right wingwall, the downstream right bank, and the upstream end of the upstream right wingwall. Type-3 stone fill (less than 48 inches diameter) was observed at the downstream end of the downstream left wingwall. Additional details describing conditions at the site are included in the Level II Summary and appendices $\mathrm{D}$ and $\mathrm{E}$.

Scour depths and recommended rock rip-rap sizes were computed using the general guidelines described in Hydraulic Engineering Circular 18 (Richardson and Davis, 1995) for the 100- and 500-year discharges. In addition, the incipient roadway-overtopping discharge was determined and analyzed as another potential worst-case scour scenario. Total scour at a highway crossing is comprised of three components: 1) long-term streambed degradation; 2) contraction scour (due to accelerated flow caused by a reduction in flow area at a bridge) and; 3 ) local scour (caused by accelerated flow around piers and abutments). Total scour is the sum of the three components. Equations are available to compute depths for contraction and local scour and a summary of the results of these computations follows.

Contraction scour for all modelled flows was zero ft. Left abutment scour ranged from 3.1 to $9.4 \mathrm{ft}$ with the worst-case occurring at the incipient roadway-overtopping discharge. Right abutment scour ranged from 5.2 to $8.7 \mathrm{ft}$ with the worst-case occurring at the 500year discharge. Additional information on scour depths and depths to armoring are included in the section titled "Scour Results". Scoured-streambed elevations, based on the calculated scour depths, are presented in tables 1 and 2. A cross-section of the scour computed at the bridge is presented in figure 8. Scour depths were calculated assuming an infinite depth of erosive material and a homogeneous particle-size distribution.

It is generally accepted that the Froehlich equation (abutment scour) gives "excessively conservative estimates of scour depths" (Richardson and Davis, 1995, p. 46). Usually, computed scour depths are evaluated in combination with other information including (but not limited to) historical performance during flood events, the geomorphic stability assessment, existing scour protection measures, and the results of the hydraulic analyses. Therefore, scour depths adopted by VTAOT may differ from the computed values documented herein. 


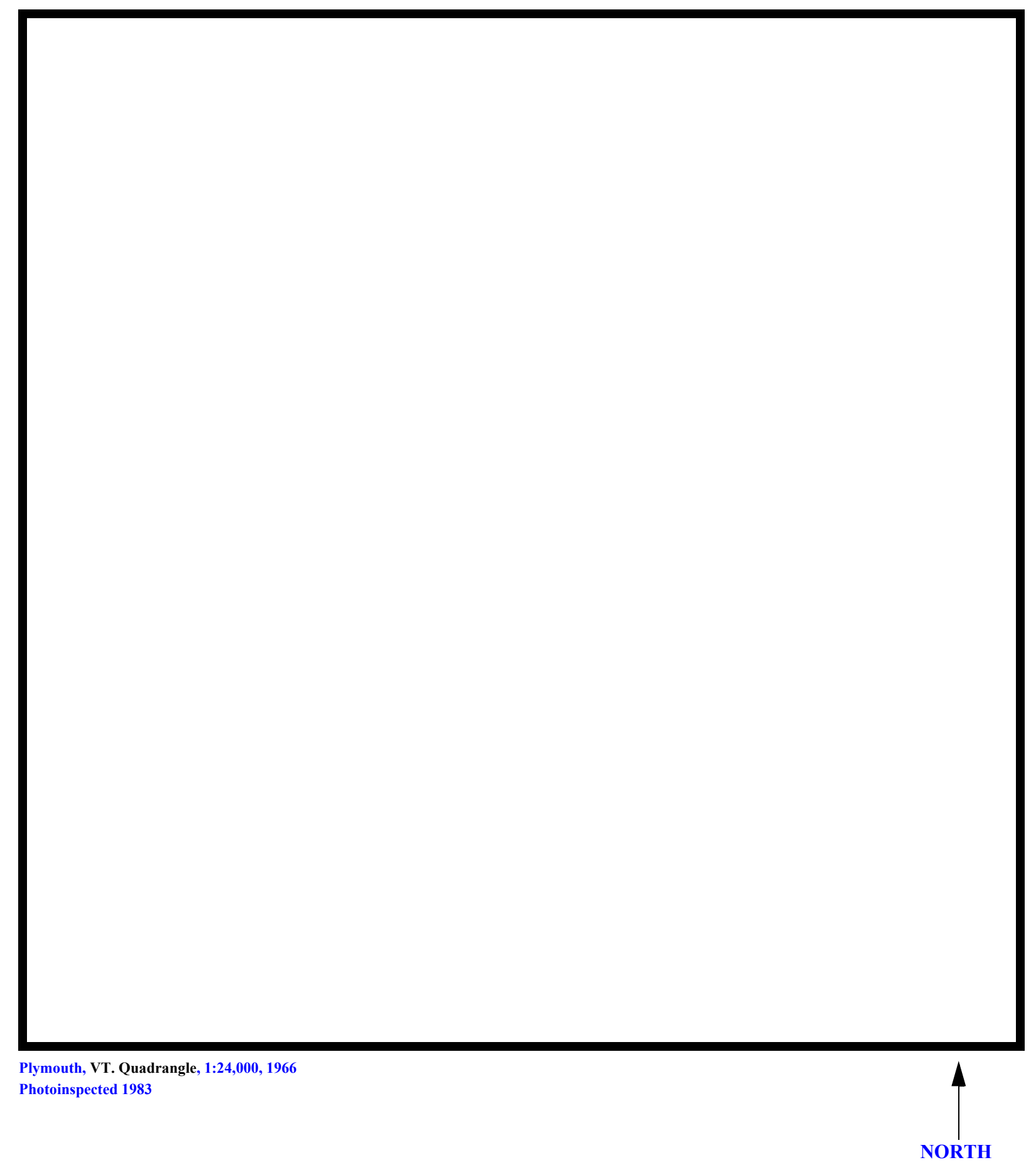

Figure 1. Location of study area on USGS 1:24,000 scale map. 
Figure 2. Location of study area on Vermont Agency of Transportation town highway map. 

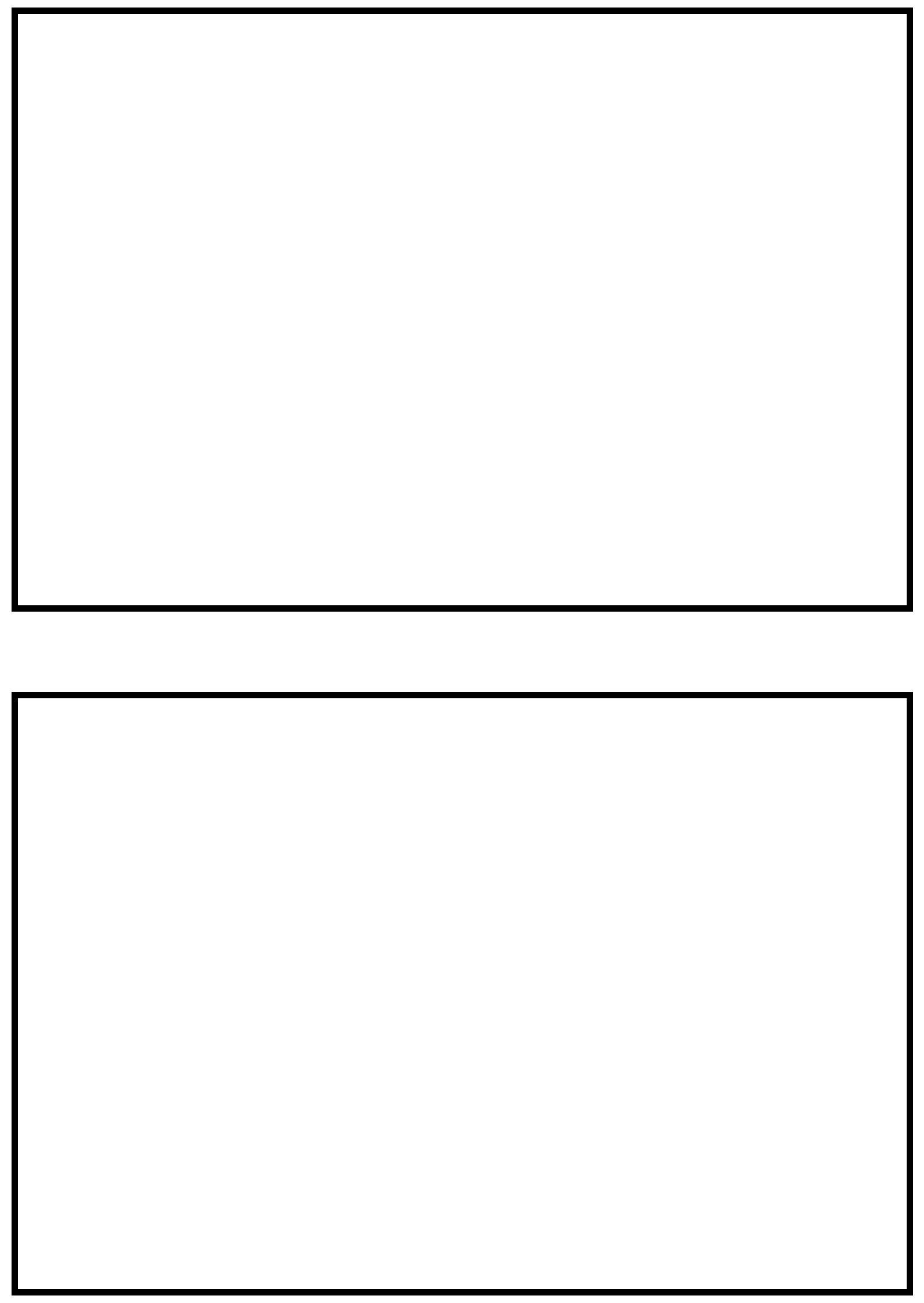

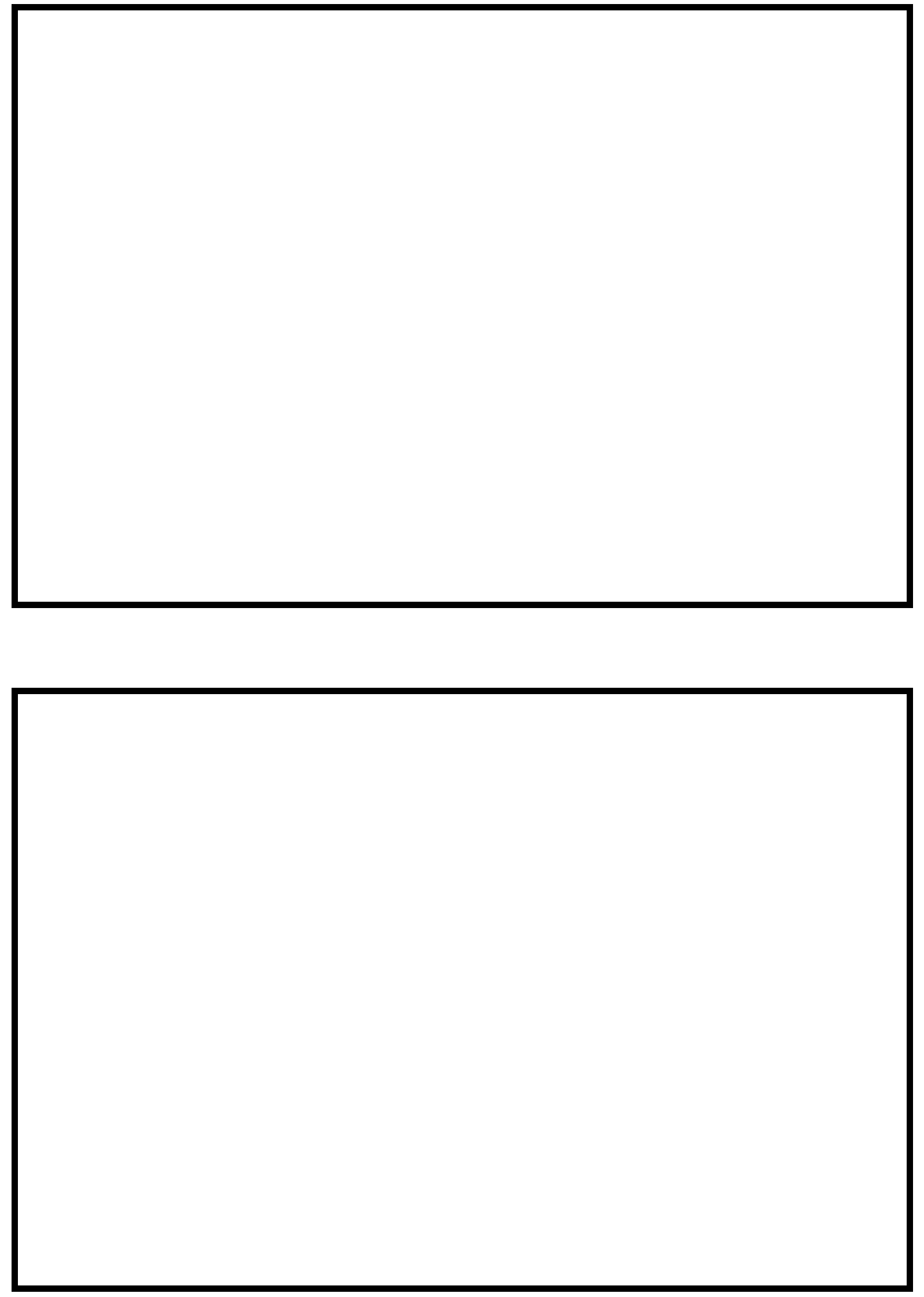


\section{LEVEL II SUMMARY}

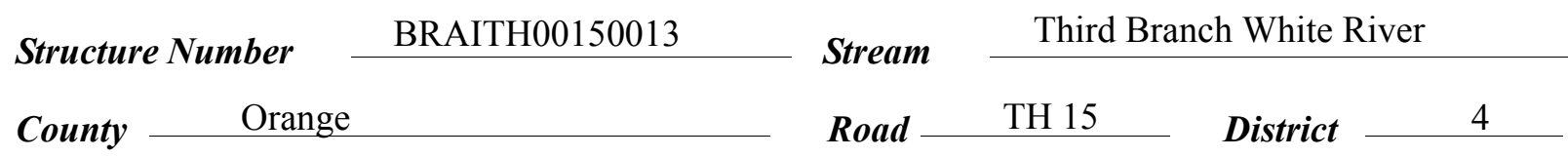

\section{Description of Bridge}

Bridge length $\frac{44}{4} \quad$ Bridge width $\frac{14.3}{f t}$ Max span length $\frac{35}{f t}$ Alignment of bridge to road (on curve or straight) Abutment type Vertical, concrete

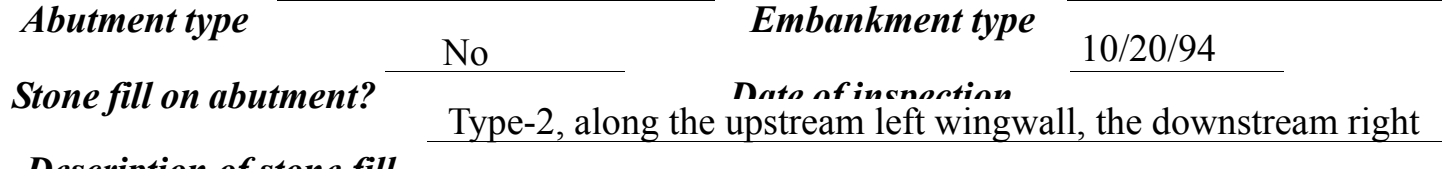
wingwall, and the upstream end of the upstream right wingwall. Type-3, at the downstream end of the downstream left wingwall.

Abutments and wingwalls are concrete. There is a one

foot deep scour hole under the bridge.

\section{Yes} 25

Is bridge skewed to flood flow according to No ' survey?
Angle

Debris accumulation on bridge at time of Level I or Level II site visit:

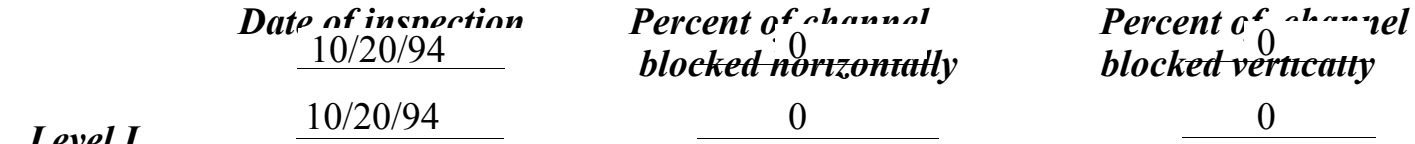

Level I

Moderate. There is some debris in the channel downstream possibly

Level II area.

Potential for debris

None, 10/20/94.

Doscriho anv fonturos noar ar at tho hridoo that mav, affort flow (includo ahsorvation dato). 


\section{Description of the Geomorphic Setting}

General topography The channel is located within a moderate relief valley with a wide flood plain.

Geomorphic conditions at bridge site: downstream (DS), upstream (US)

Date of inspection $\quad 10 / 20 / 94$

DS left: $\quad$ Steep channel bank to a wide flood plain

DS right: $\quad$ Steep valley wall

US left: $\quad$ Steep channel bank to a wide flood plain

US right: $\quad$ Steep valley wall

\section{Description of the Channel}

\begin{tabular}{llll} 
Average top width & 60 & Average depth & 6 \\
\cline { 2 - 3 } & Cobbles & Boulders/Sand
\end{tabular}

Predominant bed material Bank material Sinuous but stable

with semi-alluvial channel boundaries and random width variations" of the channel.

$10 / 20 / 94$

Vegetative co 1 Shrubs and brush

DS left: $\quad$ Shrubs and brush

DS right: $\quad$ Shrubs and brush

US left: $\quad$ Shrubs and brush with a few trees

US right: $\quad$ Yes

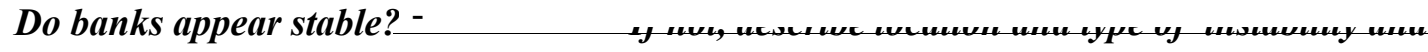

date of observatton.

None, 10/20/94.

Describe any obstructions in channel and date of observation. 


\title{
Hydrology
}

Drainage area $\stackrel{28.6}{\mathrm{mi}^{2}}$

Percentage of drainage area in physiographic provinces: (approximate)

Physiographic province/section

New England/Green Mountain
Percent of drainage area 100

\begin{abstract}
Is drainage area considered rural or urban?
Rural urbanization: None

Describe any significant
\end{abstract}

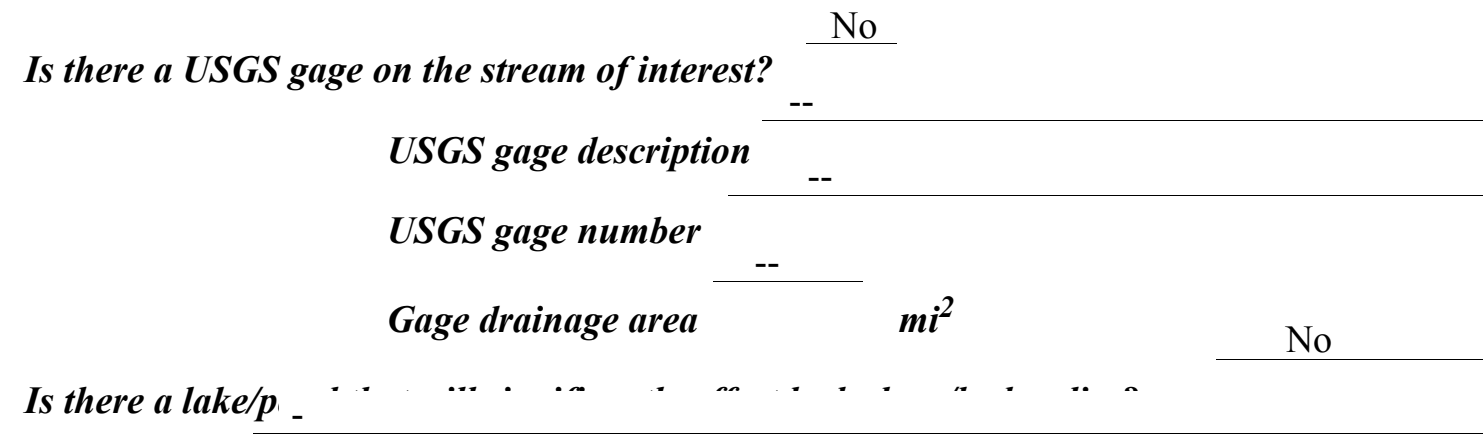

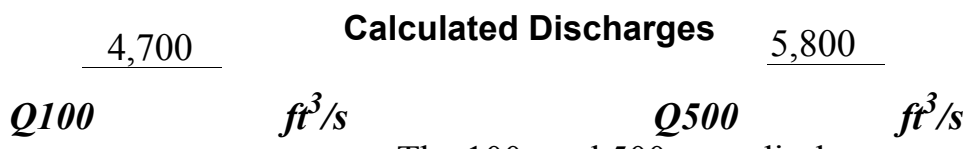

The 100- and 500-year discharges were approximated

by a drainage area relationship [(28.6/30.0)exp 0.7] with flood frequency estimates available from the VTAOT (written communication, May, 1995) for another site on the Third Branch White River and were approved by the VTAOT (written communication, September 21, 1995). The values used were within a range defined by flood frequency curves developed from several empirical methods (Benson, 1962; Johnson and Tasker, 1974; FHWA, 1983; Potter, 1957a\&b; Talbot, 1887). Each curve was extended graphically to the 500-year event. 


\section{Description of the Water-Surface Profile Model (WSPRO) Analysis}

Datum for WSPRO analysis (USGS survey, sea level, VTAOT plans)

USGS survey

Datum tie between USGS survey and VTAOT plans

None

Description of reference marks used to determine USGS datum. $\quad$ RM1 is a chiseled X on top of the downstream end of the right abutment (elev. $500.69 \mathrm{ft}$, arbitrary survey datum). RM2 is a chiseled X on top of the upstream end of the left abutment (elev. $500.63 \mathrm{ft}$, arbitrary survey datum).

\section{Cross-Sections Used in WSPRO Analysis}

\begin{tabular}{cccl}
\hline${ }^{1}$ Cross-section & $\begin{array}{c}\text { Section } \\
\text { Reference } \\
\text { Distance } \\
\text { (SRD) } \text { in feet }\end{array}$ & $\begin{array}{c}\text { 2 Cross-section } \\
\text { development }\end{array}$ & \multicolumn{1}{c}{ Comments } \\
\hline EXIT2 & -233 & 1 & Exit section \\
EXITX & -33 & 1 & Exit section \\
FULLV & 0 & 2 & $\begin{array}{l}\text { Downstream Full-valley } \\
\text { section (Templated from } \\
\text { EXITX) }\end{array}$ \\
BRIDG & 0 & 1 & $\begin{array}{l}\text { Bridge section } \\
\text { RDWAY }\end{array}$ \\
APPRO & 9 & 1 & $\begin{array}{l}\text { Road Grade section } \\
\text { Modelled Approach sec- } \\
\text { tion (Templated from }\end{array}$ \\
& 50 & 2 & $\begin{array}{l}\text { APTEM) } \\
\text { Approach section as sur- } \\
\text { APTEM }\end{array}$ \\
& 65 & 1 & $\begin{array}{l}\text { veyed (Used as a tem- } \\
\text { plate) }\end{array}$ \\
\hline
\end{tabular}

${ }^{1}$ For location of cross-sections see plan-view sketch included with Level I field form, Appendix E. For more detail on how cross-sections were developed see WSPRO input file. 


\section{Data and Assumptions Used in WSPRO Model}

Hydraulic analyses of the reach were done by use of the Federal Highway Administration's WSPRO step-backwater computer program (Shearman and others, 1986, and Shearman, 1990). The analyses reported herein reflect conditions existing at the site at the time of the study. Furthermore, in the development of the model it was necessary to assume no accumulation of debris or ice at the site. Results of the hydraulic model are presented in the Bridge Hydraulic Summary, appendix B, and figure 7.

Channel roughness factors (Manning's " $n$ ") used in the hydraulic model were estimated using field inspections at each cross section following the general guidelines described by Arcement and Schneider (1989). Final adjustments to the values were made during the modelling of the reach. Channel " $n$ " values for the reach ranged from 0.040 to 0.045 , and overbank " $n$ " values ranged from 0.035 to 0.061 .

Normal depth at the exit section (EXIT2) was assumed as the starting water surface. This depth was computed by use of the slope-conveyance method outlined in the user's manual for WSPRO (Shearman, 1990). The slope used was $0.0017 \mathrm{ft} / \mathrm{ft}$, which was estimated from thalweg points surveyed downstream of the bridge.

The surveyed approach section (APTEM) was moved along the approach channel slope $(0.01 \mathrm{ft} / \mathrm{ft})$ to establish the modelled approach section (APPRO), one bridge length upstream of the upstream face as recommended by Shearman and others (1986). This location provides a consistent method for determining scour variables. 


\section{Bridge Hydraulics Summary}

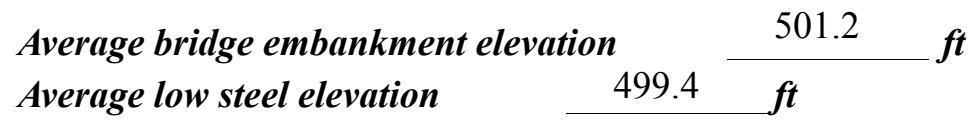

$$
\text { 100-year discharge } \quad 4,700 \quad \mathrm{ft}^{3} / \mathrm{s}
$$

Water-surface elevation in bridge opening $\quad 499.5 \mathrm{ft}$

Road overtopping? ___ Yes Discharge over road _ـ 4,070 $\mathrm{ft}^{3} / \mathrm{s}$

\begin{tabular}{llll} 
Area of flow in bridge opening & $262 \quad \mathrm{ft}^{2}$ \\
\cline { 2 - 3 } Average velocity in bridge opening & 2.5 & $\mathrm{ft} / \mathrm{s}$
\end{tabular}

Maximum WSPRO tube velocity at bridge $\quad 3.0 \mathrm{ft} / \mathrm{s}$

Water-surface elevation at Approach section with bridge 500.3

Water-surface elevation at Approach section without bridge $\quad 500.2$

Amount of backwater caused by bridge $\quad 0.1 \quad$ it

500-year discharge $\quad 5,800 \quad \mathrm{ft}^{3} / \mathrm{s}$

Water-surface elevation in bridge opening $\quad 499.5 \mathrm{ft}$

Road overtopping? ___ Yes Discharge over road _ $\quad 5,210, t^{3} / \mathbf{s}$

$\begin{array}{llll}\text { Area of flow in bridge opening } & 262 & \boldsymbol{f t}^{2} & \\ \text { Average velocity in bridge opening } & & 2.2 & \mathrm{ft} / \mathrm{s}\end{array}$

Maximum WSPRO tube velocity at bridge $\quad 2.6$ 's

Water-surface elevation at Approach section with bridge 500.7

Water-surface elevation at Approach section without bridge $\quad 500.6$

Amount of backwater caused by bridge $0.1, t$

Incipient overtopping discharge $\quad 1,450 \quad \mathrm{ft}^{3} / \mathrm{s}$

Water-surface elevation in bridge opening 497.2 t

Area of flow in bridge opening $\quad 195 \quad \mathrm{ft}^{2}$

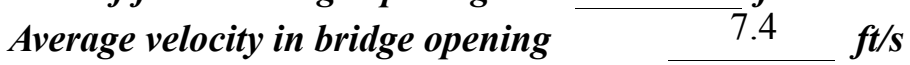

Maximum WSPRO tube velocity at bridge $\quad 9.3 \mathrm{ft} / \mathrm{s}$

Water-surface elevation at Approach section with bridge

Water-surface elevation at Approach section without bridge

497.7.

Amount of backwater caused by bridge $\quad 0.2$, t

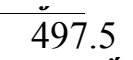




\section{Scour Analysis Summary}

\section{Special Conditions or Assumptions Made in Scour Analysis}

Scour depths were computed using the general guidelines described in Hydraulic Engineering Circular 18 (Richardson and Davis, 1995). Scour depths were calculated assuming an infinite depth of erosive material and a homogeneous particle-size distribution. The results of the scour analyses for the 100- and 500-year discharges are presented in tables 1 and 2 and the scour depths are shown graphically in figure 8 .

Contraction scour for the incipient roadway-overtopping discharge was computed by use of the Laursen clear-water contraction scour equation (Richardson and Davis, 1995, p. 32 , equation 20). At this site, the 100-year and 500-year discharges resulted in submerged orifice flow. Contraction scour at bridges with orifice flow is best estimated by use of the Chang pressure-flow scour equation (oral communication, J. Sterling Jones, October 4, 1996). Thus, contraction scour for these discharges was computed by use of the Chang equation (Richardson and Davis, 1995, p. 145-146).

For comparison, contraction scour for the discharges resulting in orifice flow was computed by use of the Laursen clear-water contraction scour equation and the Umbrell pressure-flow equation (Richardson and Davis, 1995, p. 144). Results from these computations are presented in appendix F.

Abutment scour was computed by use of the Froehlich equation (Richardson and Davis, 1995, p. 48, equation 28) at the right abutment for all modelled flows and at the left abutment for the incipient roadway-overtopping discharge. Variables for the Froehlich equation include the Froude number of the flow approaching the embankments, the length of the embankment blocking flow, and the depth of flow approaching the embankment less any roadway overtopping.

Abutment scour was computed by use of the HIRE equation (Richardson and Davis, 1995, p. 49, equation 29) at the left abutment for the 100-year and 500-year discharges because the HIRE equation is recommended when the length to depth ratio of the embankment blocking flow exceeds 25 . The variables used by the HIRE abutment-scour equation are defined the same as those defined for the Froehlich abutment-scour equation. 


\section{Scour Results}

Contraction scour:

Main channel

Live-bed scour

Clear-water scour

Depth to armoring

Left overbank

Right overbank

Local scour:

Abutment scour

Left abutment

Right abutment

Pier scour

Pier 1

Pier 2

Pier 3

100-year
discharge 500-year discharge

(Scour depths in feet)

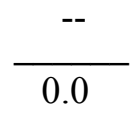

$0.0^{-}$
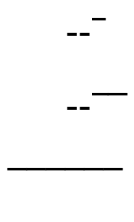


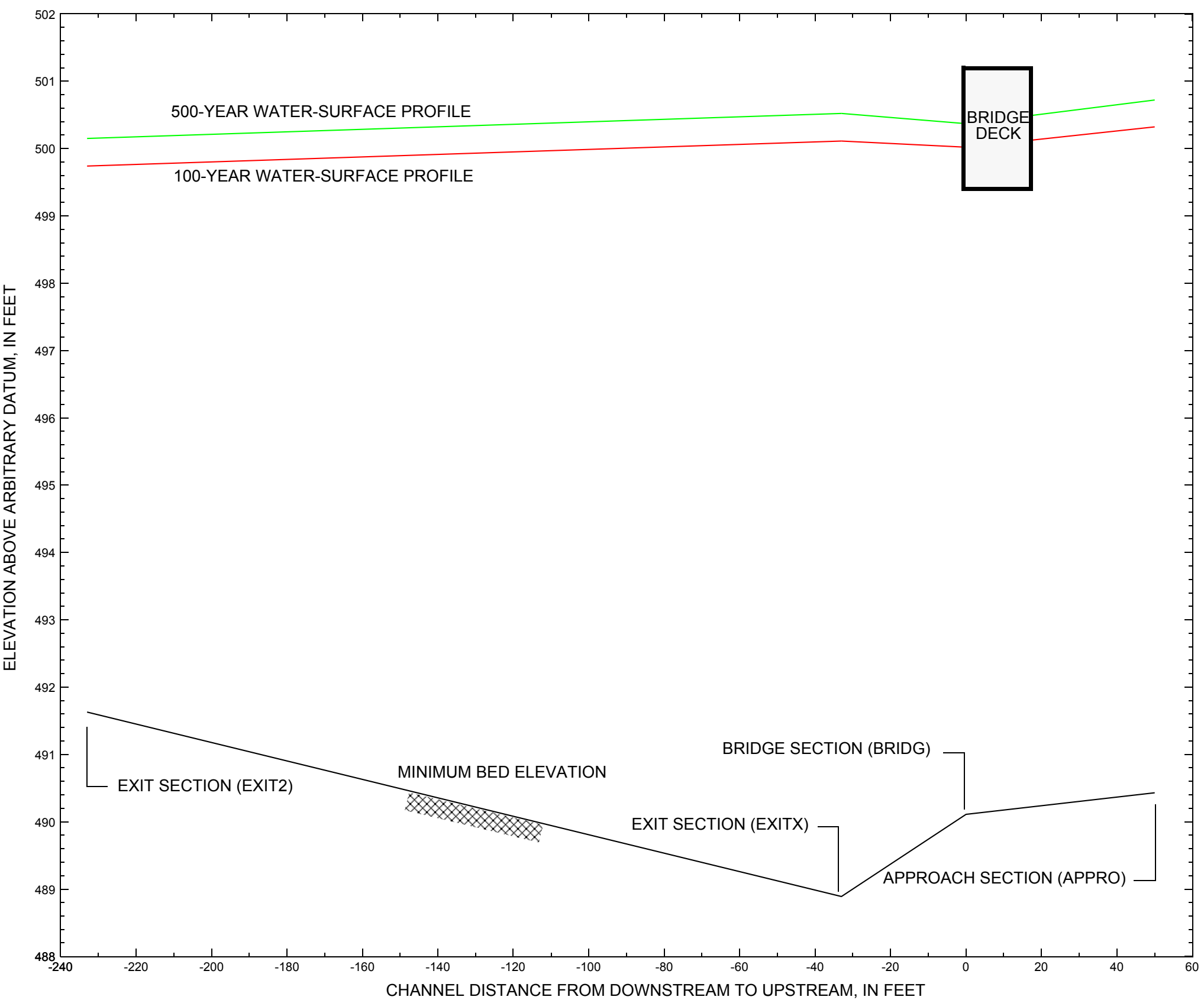

Figure 7. Water-surface profiles for the 100- and 500-year discharges at structure BRAITH00150013 on Town Highway 15, crossing the Third Branch White River, Braintree, Vermont. 


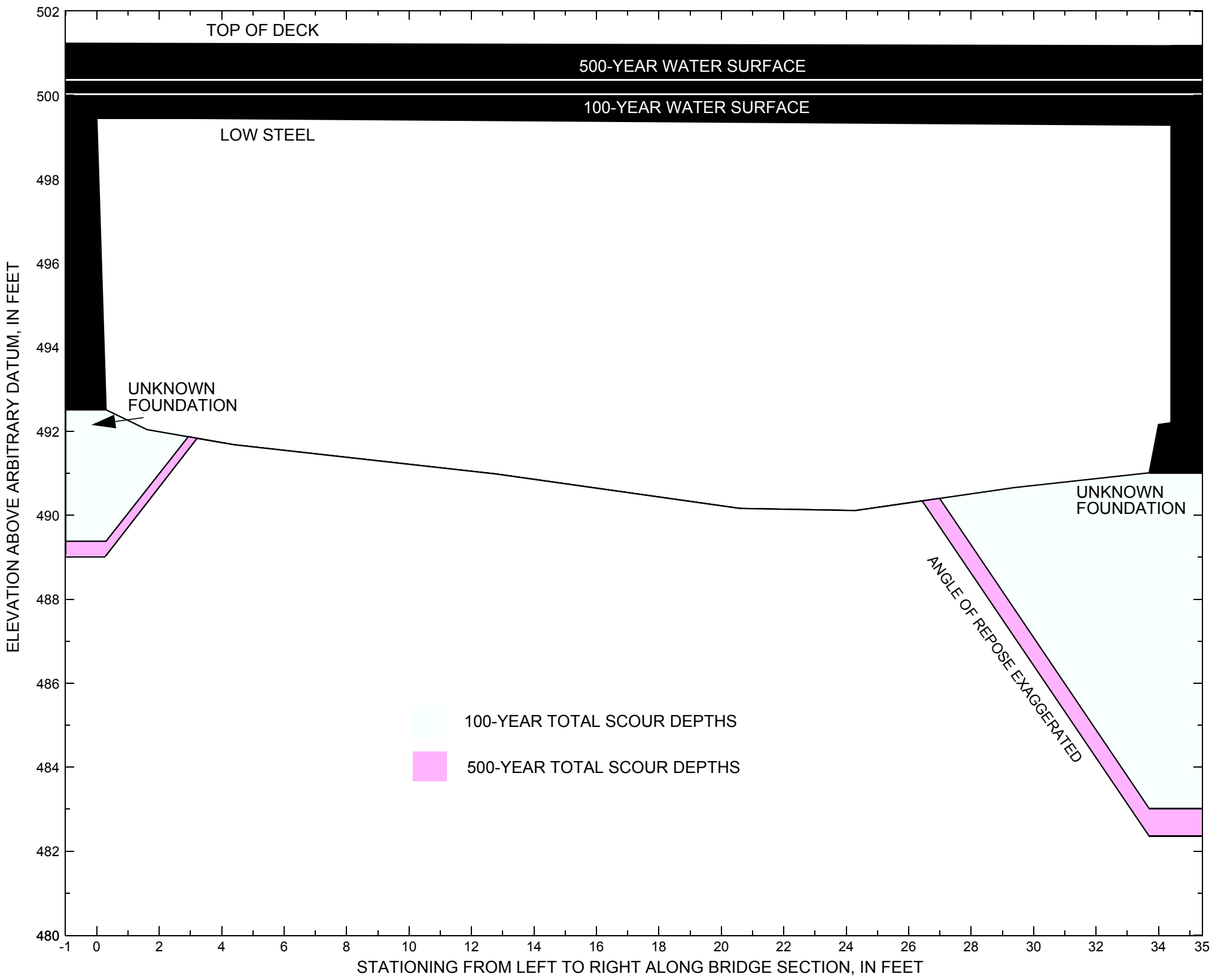

Figure 8. Scour elevations for the 100- and 500-year discharges at structure BRAITH00150013 on Town Highway 15, crossing the Third Branch White River, Braintree, Vermont. 
Table 1. Remaining footing/pile depth at abutments for the 100-year discharge at structure BRAITH00150013 on Town Highway 15, crossing the Third Branch White River, Braintree, Vermont.

[VTAOT, Vermont Agency of Transportation; --, no data]

\begin{tabular}{|c|c|c|c|c|c|c|c|c|c|c|c|}
\hline Description & Station $^{1}$ & $\begin{array}{l}\text { VTAOT } \\
\text { minimum } \\
\text { low-chord } \\
\text { elevation } \\
\text { (feet) }\end{array}$ & $\begin{array}{c}\text { Surveyed } \\
\text { minimum } \\
\text { low-chord } \\
\text { elevation } \\
\text { (feet) }\end{array}$ & $\begin{array}{c}\text { Bottom of } \\
\text { footing/pile } \\
\text { elevation } \\
\text { (feet) }\end{array}$ & $\begin{array}{l}\text { Channel } \\
\text { elevation at } \\
\text { abutment/ } \\
\text { pier }^{2} \\
\text { (feet) }\end{array}$ & $\begin{array}{l}\text { Contraction } \\
\text { scour depth } \\
\text { (feet) }\end{array}$ & $\begin{array}{l}\text { Abutment } \\
\text { scour } \\
\text { depth } \\
\text { (feet) }\end{array}$ & $\begin{array}{l}\text { Pier } \\
\text { scour } \\
\text { depth } \\
\text { (feet) }\end{array}$ & $\begin{array}{l}\text { Depth of } \\
\text { total scour } \\
\text { (feet) }\end{array}$ & $\begin{array}{c}\text { Elevation of } \\
\text { scour }^{2} \\
\text { (feet) }\end{array}$ & $\begin{array}{c}\text { Remaining } \\
\text { footing/pile } \\
\text { depth } \\
\text { (feet) }\end{array}$ \\
\hline \multicolumn{12}{|c|}{100 -year discharge is 4,700 cubic-feet per second } \\
\hline Left abutment & 0.0 & -- & 499.5 & -- & 492.5 & 0.0 & 3.1 & -- & 3.1 & 489.4 & -- \\
\hline Right abutment & 34.4 & -- & 499.3 & -- & 491.0 & 0.0 & 8.0 & -- & 8.0 & 483.0 & -- \\
\hline
\end{tabular}

1.Measured along the face of the most constricting side of the bridge.

2.Arbitrary datum for this study.

Table 2. Remaining footing/pile depth at abutments for the 500-year discharge at structure BRAITH00150013 on Town Highway 15, crossing the Third Branch White River, Braintree, Vermont.

[VTAOT, Vermont Agency of Transportation; --, no data]

\begin{tabular}{|c|c|c|c|c|c|c|c|c|c|c|c|}
\hline Description & Station $^{1}$ & $\begin{array}{l}\text { VTAOT } \\
\text { minimum } \\
\text { low-chord } \\
\text { elevation } \\
\text { (feet) }\end{array}$ & $\begin{array}{c}\text { Surveyed } \\
\text { minimum } \\
\text { low-chord } \\
\text { elevation } \\
\text { (feet) }\end{array}$ & $\begin{array}{c}\text { Bottom of } \\
\text { footing/pile } \\
\text { elevation } \\
\text { (feet) }\end{array}$ & $\begin{array}{c}\text { Channel } \\
\text { elevation at } \\
\text { abutment/ } \\
\text { pier }^{2} \\
\text { (feet) }\end{array}$ & $\begin{array}{l}\text { Contraction } \\
\text { scour depth } \\
\text { (feet) }\end{array}$ & $\begin{array}{c}\text { Abutment } \\
\text { scour } \\
\text { depth } \\
\text { (feet) }\end{array}$ & $\begin{array}{l}\text { Pier } \\
\text { scour } \\
\text { depth } \\
\text { (feet) }\end{array}$ & $\begin{array}{l}\text { Depth of } \\
\text { total scour } \\
\text { (feet) }\end{array}$ & $\begin{array}{c}\text { Elevation of } \\
\text { scour }^{2} \\
\text { (feet) }\end{array}$ & $\begin{array}{c}\text { Remaining } \\
\text { footing/pile } \\
\text { depth } \\
\text { (feet) }\end{array}$ \\
\hline \multicolumn{12}{|c|}{500 -year discharge is 5,800 cubic-feet per second } \\
\hline Left abutment & 0.0 & -- & 499.5 & -- & 492.5 & 0.0 & 3.5 & -- & 3.5 & 489.0 & -- \\
\hline Right abutment & 34.4 & -- & 499.3 & -- & 491.0 & 0.0 & 8.7 & -- & 8.7 & 482.3 & -- \\
\hline
\end{tabular}

1.Measured along the face of the most constricting side of the bridge.

2.Arbitrary datum for this study. 


\section{SELECTED REFERENCES}

Arcement, G.J., Jr., and Schneider, V.R., 1989, Guide for selecting Manning's roughness coefficients for natural channels and flood plains: U.S. Geological Survey Water-Supply Paper 2339, 38 p.

Barnes, H.H., Jr., 1967, Roughness characteristics of natural channels: U.S. Geological Survey Water-Supply Paper 1849,213 p.

Benson, M. A., 1962, Factors Influencing the Occurrence of Floods in a Humid Region of Diverse Terrain: U.S. Geological Survey WaterSupply Paper 1580-B, 64 p.

Brown, S.A. and Clyde, E.S., 1989, Design of riprap revetment: Federal Highway Administration Hydraulic Engineering Circular No. 11, Publication FHWA-IP-89-016, 156 p.

Federal Highway Administration, 1983, Runoff estimates for small watersheds and development of sound design: Federal Highway Administration Report FHWA-RD-77-158.

Federal Highway Administration, 1993, Stream Stability and Scour at Highway Bridges: Participant Workbook: Federal Highway Administration Report FHWA-HI-91-011.

Froehlich, D.C., 1989, Local scour at bridge abutments in Ports, M.A., ed., Hydraulic Engineering--Proceedings of the 1989 National Conference on Hydraulic Engineering: New York, American Society of Civil Engineers, p. 13-18.

Hayes, D.C.,1993, Site selection and collection of bridge-scour data in Delaware, Maryland, and Virginia: U.S. Geological Survey WaterResources Investigation Report 93-4017, 23 p.

Interagency Advisory Committee on Water Data, 1982, Guidelines for determining flood flow frequency: U.S. Geological Survey, Bulletin 17B of the Hydrology Subcommittee, 190 p.

Johnson, C.G. and Tasker, G.D.,1974, Progress report on flood magnitude and frequency of Vermont streams: U.S. Geological Survey OpenFile Report 74-130, 37 p.

Lagasse, P.F., Schall, J.D., Johnson, F., Richardson, E.V., Chang, F., 1995, Stream Stability at Highway Structures: Federal Highway Administration Hydraulic Engineering Circular No. 20, Publication FHWA-IP-90-014, 144 p.

Laursen, E.M., 1960, Scour at bridge crossings: Journal of the Hydraulics Division, American Society of Civil Engineers, v. 86, no. HY2, p. 39-53.

Potter, W. D., 1957a, Peak rates of runoff in the Adirondack, White Mountains, and Maine woods area, Bureau of Public Roads

Potter, W. D., 1957b, Peak rates of runoff in the New England Hill and Lowland area, Bureau of Public Roads

Richardson, E.V. and Davis, S.R., 1995, Evaluating scour at bridges: Federal Highway Administration Hydraulic Engineering Circular No. 18, Publication FHWA-IP-90-017, 204 p.

Richardson, E.V., Simons, D.B., and Julien, P.Y., 1990, Highways in the river environment: Federal Highway Administration Publication FHWA-HI-90-016.

Ritter, D.F., 1984, Process Geomorphology: W.C. Brown Co., Debuque, Iowa, 603 p.

Shearman, J.O., 1990, User's manual for WSPRO--a computer model for water surface profile computations: Federal Highway Administration Publication FHWA-IP-89-027, 187 p.

Shearman, J.O., Kirby, W.H., Schneider, V.R., and Flippo, H.N., 1986, Bridge waterways analysis model; research report: Federal Highway Administration Publication FHWA-RD-86-108, 112 p.

Talbot, A.N., 1887, The determination of water-way for bridges and culverts.

U.S. Geological Survey, 1970, Warren, Vermont 7.5 Minute Series quadrangle map: U.S. Geological Survey Topographic Maps, Photoinspected 1983, Scale 1:24,000. 


\section{APPENDIX A: \\ WSPRO INPUT FILE}




\section{WSPRO INPUT FILE}

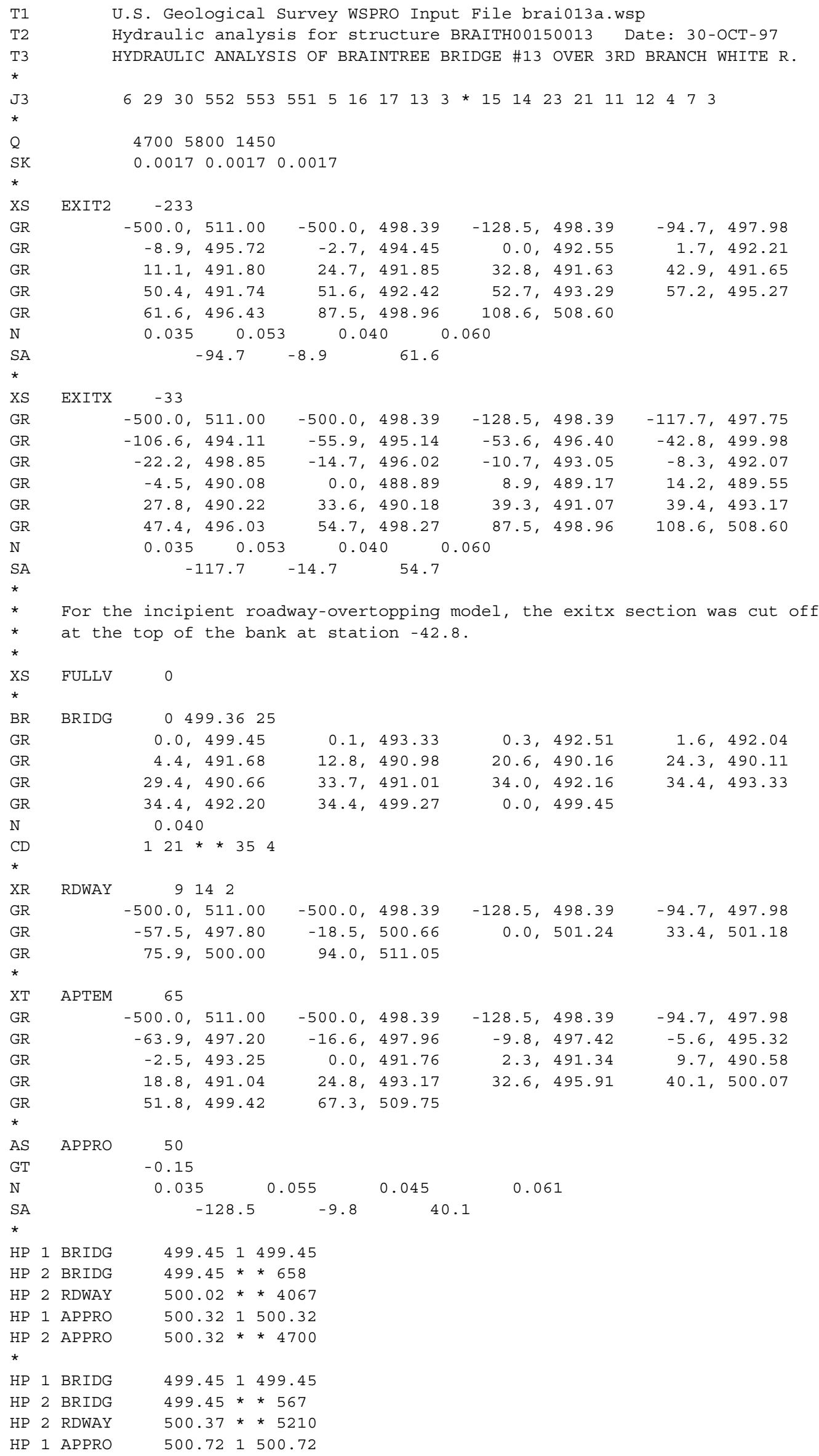




\section{APPENDIX B: \\ WSPRO OUTPUT FILE}




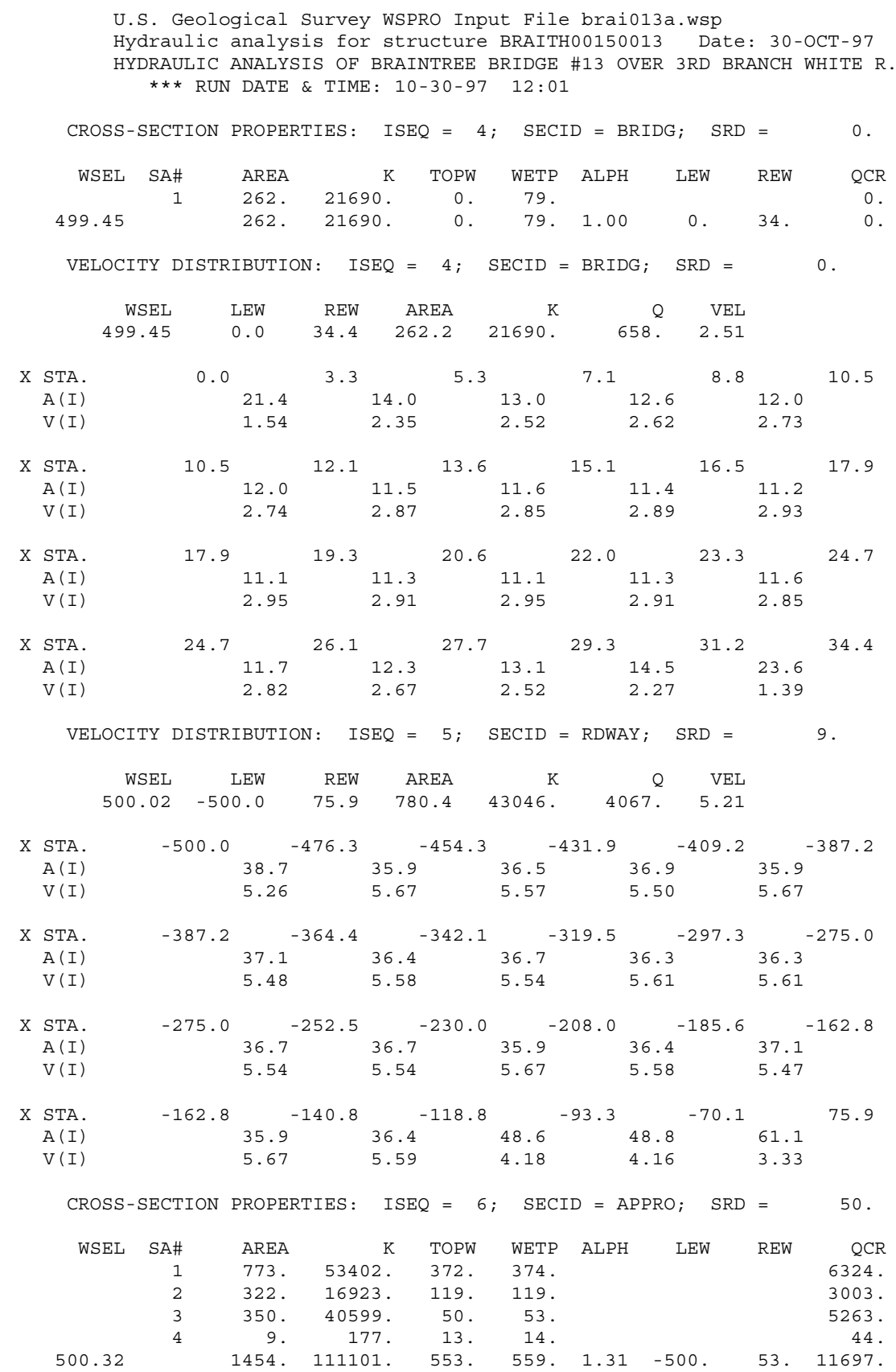

VELOCITY DISTRIBUTION $:$ ISEQ $=6 ; \operatorname{SECID}=\operatorname{APPRO} ; \quad \operatorname{SRD}=50$.

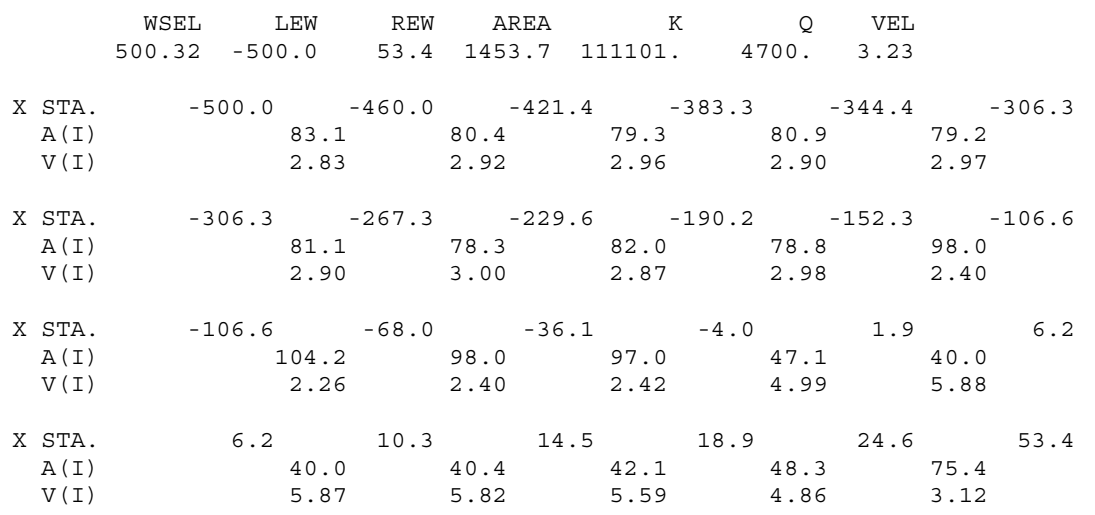




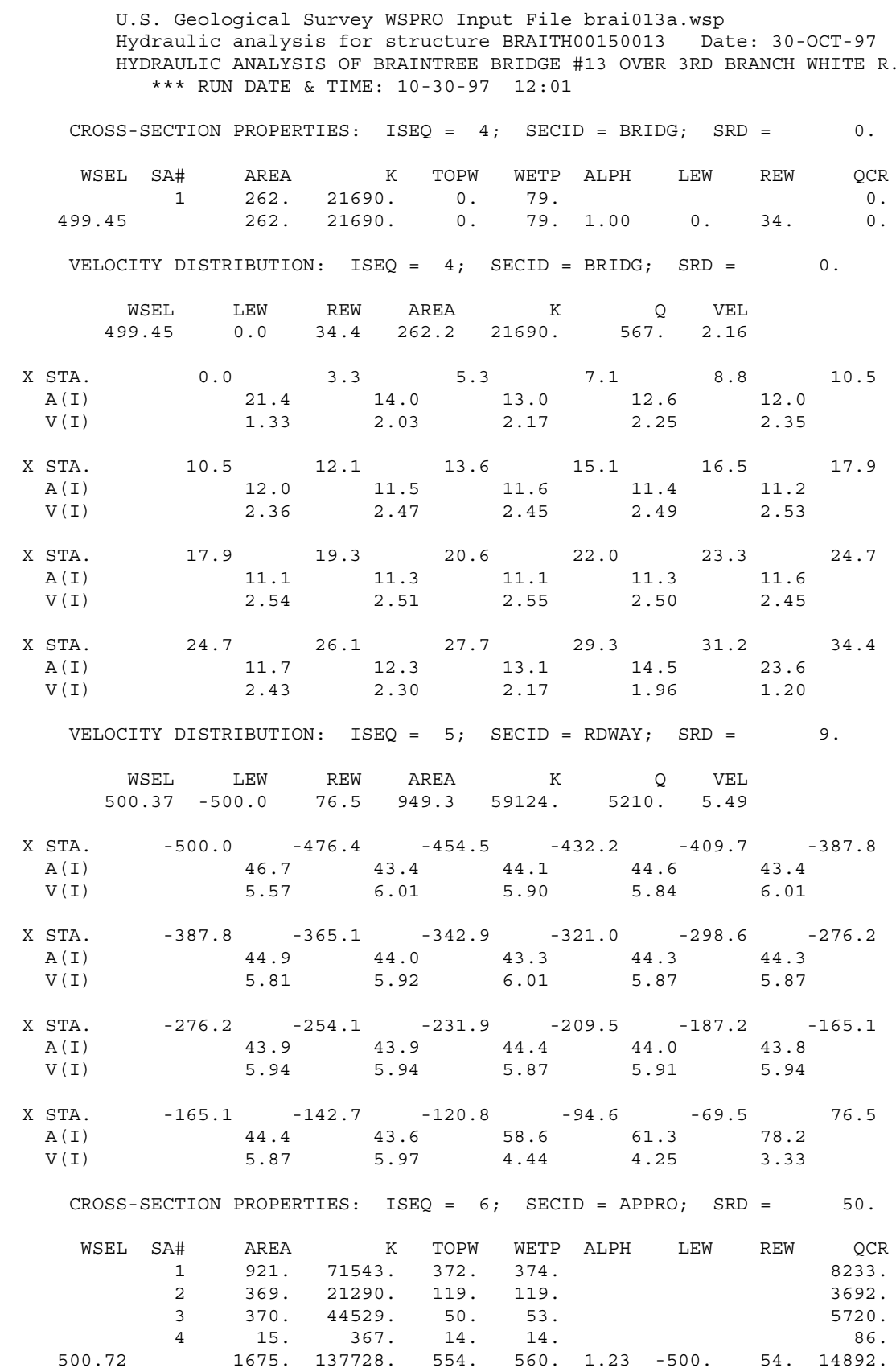

VELOCITY DISTRIBUTION $:$ ISEQ $=6 ; \operatorname{SECID}=\operatorname{APPRO} ; \quad \operatorname{SRD}=50$.

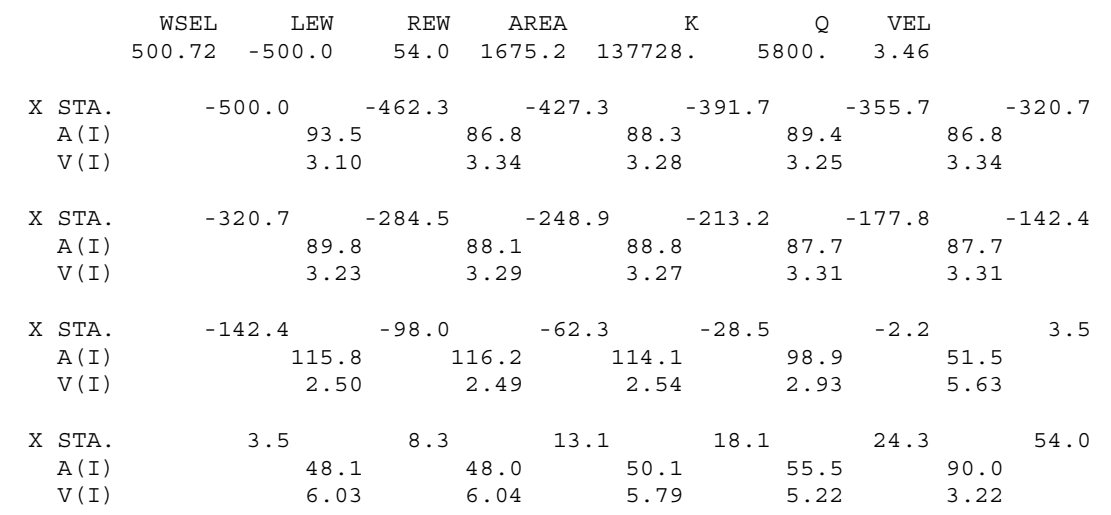


WSPRO OUTPUT FILE (continued)

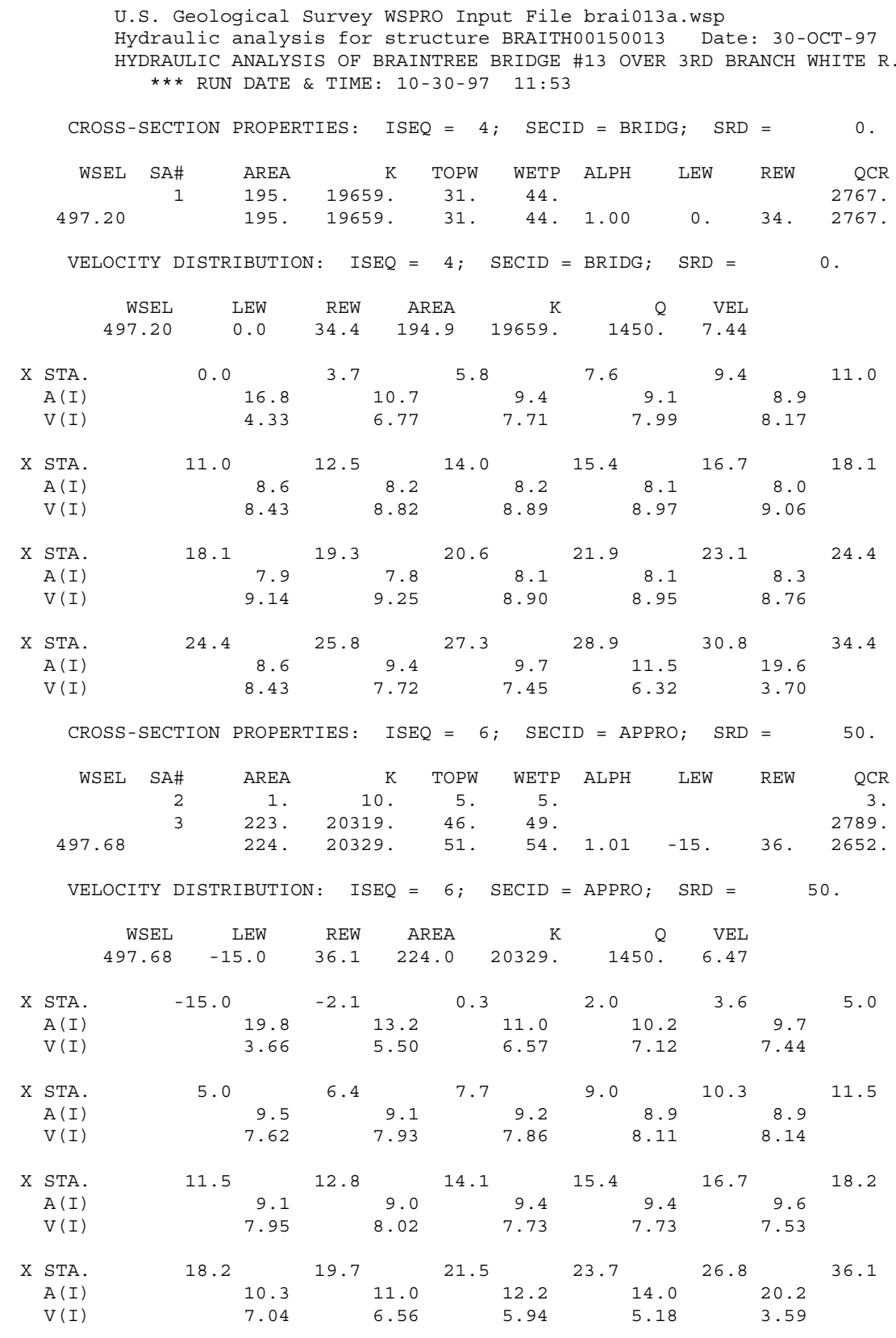


WSPRO OUTPUT FILE (continued)

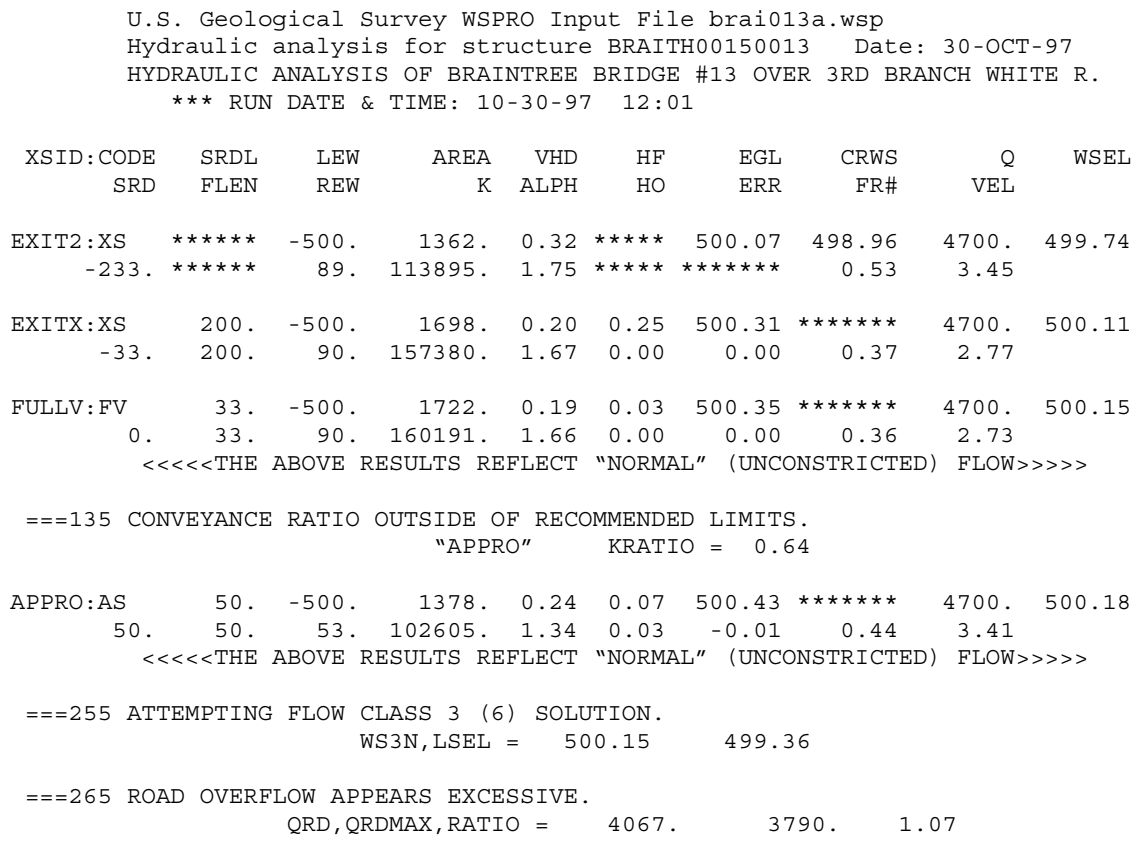


WSPRO OUTPUT FILE (continued)

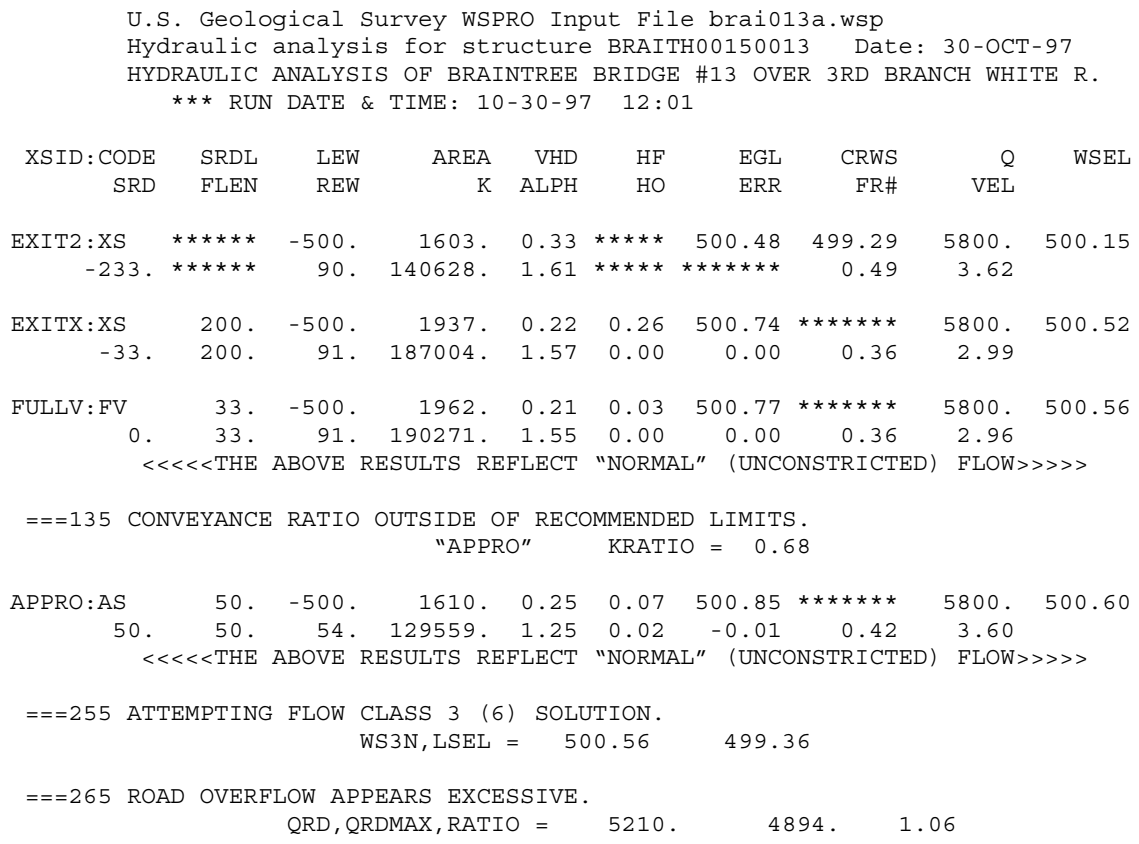


WSPRO OUTPUT FILE (continued)

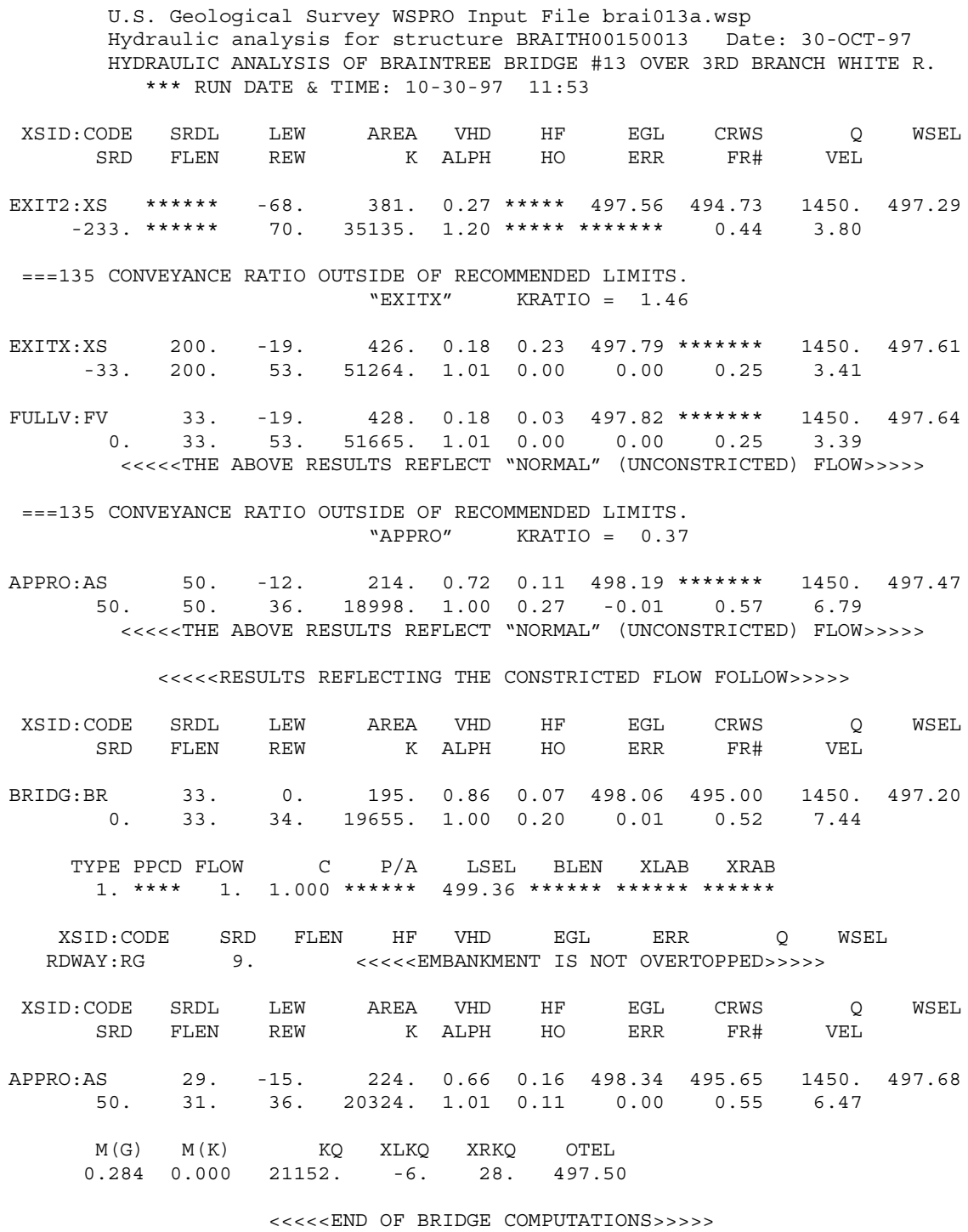

FIRST USER DEFINED TABLE.

\begin{tabular}{|c|c|c|c|c|c|c|c|c|}
\hline XSID : CODE & SRD & LEW & REW & $Q$ & $\mathrm{~K}$ & AREA & VEL & WSEL \\
\hline EXIT2:XS & -233. & -68 & 70. & 1450. & 35135 . & 381. & 3.80 & 497.29 \\
\hline EXITX:XS & -33 & -19 & 53. & 1450 . & 51264. & 426. & 3.41 & 497.61 \\
\hline FULLV : FV & 0 . & -19 & 53. & 1450. & 51665. & 428 . & 3.39 & 497.64 \\
\hline BRIDG : BR & 0 . & 0 & 34. & 1450. & 19655. & 195. & 7.44 & 497.20 \\
\hline RDWAY : RG & \multicolumn{3}{|c|}{ 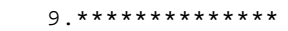 } & \multicolumn{3}{|c|}{$0 . * * * * * * * * * * * * * * * * * *$} & \multicolumn{2}{|c|}{$2.00 * * * * \star * * *$} \\
\hline APPRO : AS & 50. & -15 & 36. & 1450. & 20324 . & 224 . & 6.47 & 497.68 \\
\hline XSID : CODE & XLKQ & $\mathrm{XRKQ}$ & & & & & & \\
\hline APPRO : AS & -6. & 28. & 21152 & & & & & \\
\hline
\end{tabular}

SECOND USER DEFINED TABLE.

$\begin{array}{lcrrrrrrrr}\text { XSID :CODE } & \text { CRWS } & \text { FR\# } & \text { YMIN } & \text { YMAX } & \text { HF } & \text { HO } & \text { VHD } & \text { EGL } & \text { WSEL } \\ \text { EXIT2:XS } & 494.73 & 0.44 & 491.63 & 511.00 * * * * * * * * * * * & 0.27 & 497.56 & 497.29 \\ \text { EXITX:XS } & * * * * * * * & 0.25 & 488.89 & 511.00 & 0.23 & 0.00 & 0.18 & 497.79 & 497.61 \\ \text { FULLV:FV } & * * * * * * * * & 0.25 & 488.89 & 511.00 & 0.03 & 0.00 & 0.18 & 497.82 & 497.64 \\ \text { BRIDG :BR } & 495.00 & 0.52 & 490.11 & 499.45 & 0.07 & 0.20 & 0.86 & 498.06 & 497.20 \\ \text { RDWAY:RG } & * * * * * * * * * * * * * * * & 497.80 & 511.05 * * * * * * * * * * * * * * * * * * * * * * * * * * * * * * * \\ \text { APPRO:AS } & 495.65 & 0.55 & 490.43 & 510.85 & 0.16 & 0.11 & 0.66 & 498.34 & 497.68\end{array}$




\section{APPENDIX C:}

\section{BED-MATERIAL PARTICLE-SIZE DISTRIBUTION}




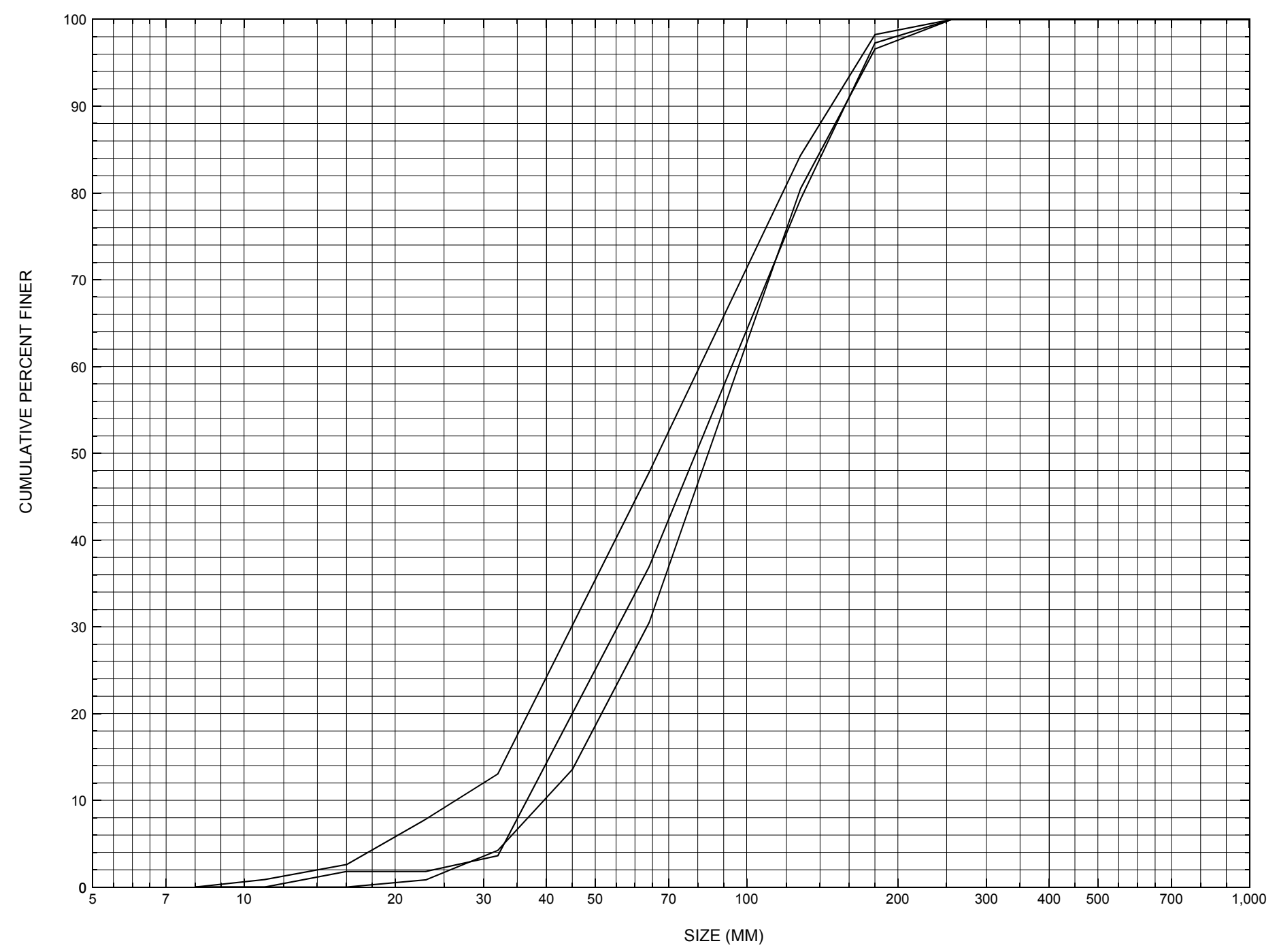

Appendix C. Bed material particle-size distribution for three pebble counts in the channel approach of structure BRAITH00150013, in Braintree, Vermont. 


\section{APPENDIX D: \\ HISTORICAL DATA FORM}




\section{Structure Number BRAITH00150013}

\section{General Location Descriptive}

Data collected by (First Initial, Full last name) $\mathbf{E}$. BOEHMLER

Date $(M M / D D / Y Y) \_\mathbf{0 8} / \underline{\mathbf{2 4}} / \underline{\mathbf{9 4}}$

Highway District Number (I - 2; nn) $\mathbf{0 4}$

Town (FIPS place code; I - 4; nnnnn)

Waterway (I - 6) 3RD BRANCH WHITE RIVER

Route Number TH015

Topographic Map Warren

Latitude (I - 16; nnnn.n) $\mathbf{4 4 0 0 3}$
County (FIPS county code; I - 3; nnn)

Mile marker (I - 11; nnn.nnn) $\mathbf{0 0 0 0 0 0}$

Road Name (I - 7): -

Vicinity (I - 9) 0.2 MI JCT TH 15 + VT12A

Hydrologic Unit Code: $\mathbf{0 1 0 8 0 1 0 5}$

Longitude (i - 17; nnnnn.n) 72499

\section{Select Federal Inventory Codes}

FHWA Structure Number (I - 8) $\mathbf{1 0 0 9 0 2 0 0 1 3 0 9 0 2}$

Maintenance responsibility $(I-21 ; n n) \quad \mathbf{0 3}$

Year built (I - 27; YYYY) 1971

Average daily traffic, ADT (I - 29; nnnnnn) $\underline{000020}$

Year of ADT (I - 30; YY) $\underline{\mathbf{9 1}}$

Opening skew to Roadway $(I-34 ; n n) \quad \mathbf{0 0}$

Operational status $(I-41 ; X) \quad$ B

Structure type (I- 43; nnn) $\mathbf{3 0 2}$

Approach span structure type $(I-44 ; n n n)$ 000

Number of spans (I - 45; nnn) $\underline{\mathbf{0 0 1}}$

Number of approach spans (I - 46; nnnn) $\mathbf{0 0 0 0}$

Comments:

The structural inspection report of 4/27/93 indicates the structure is a steel I-beam bridge with a timber deck and a narrow gravel road approach surface. The report indicates the abutment and wingwall concrete is in "like new" condition. Both abutment footings are reported as exposed. The exposure ranges from the top of the footing flush with the streambed at the upstream end of the left abutment to 1 foot exposure at the downstream end. For the right abutment, the footing top is exposed at the downstream end and there is 1 foot of exposure at the upstream end. The report indicates no change in channel scour from prior inspections and no embankment erosion. There is no vegetation buildup near the bridge. Channel alignment is noted as straight into the bridge crossing. Stone fill is reported as boulders in good condition. 


\section{Bridge Hydrologic Data}

Is there hydrologic data available? $\mathbf{N}$ if No, type ctrl- $n$ VTAOT Drainage area $\left(\mathrm{mi}^{2}\right)^{2}$ : -

Terrain character:

Stream character \& type: -

Streambed material: Sand and gravel and some larger stones

Discharge Data (cfs): $\quad \mathrm{Q}_{2.33}$

$$
\mathrm{Q}_{50}
$$

$\mathrm{Q}_{25}$

$\mathrm{Q}_{500}$

Record flood date $(M M / D D / Y Y):-$

Water surface elevation $(f t):-$

Estimated Discharge (cfs): Velocity at $\mathrm{Q}-$ $(\mathrm{ft} / \mathrm{s}):$

Ice conditions (Heavy, Moderate, Light) : -

Debris (Heavy, Moderate, Light):

The stage increases to maximum highwater elevation (Rapidly, Not rapidly):

The stream response is (Flashy, Not flashy):

Describe any significant site conditions upstream or downstream that may influence the stream's stage: -

Watershed storage area (in percent): - $\%$

The watershed storage area is: - _ (1-mainly at the headwaters; 2- uniformly distributed; 3-immediatly upstream oi the site)

Water Surface Elevation Estimates for Existing Structure:

\begin{tabular}{|l|l|l|l|l|l|}
\hline Peak discharge frequency & $Q_{2.33}$ & $Q_{10}$ & $Q_{25}$ & $Q_{50}$ & $Q_{100}$ \\
Water surface elevation (ft)) & - & - & - & - & - \\
Velocity (ft/sec) & - & - & - & - & - \\
\hline
\end{tabular}

Long term stream bed changes: -

Is the roadway overtopped below the $\mathrm{Q}_{100}$ ? (Yes, No, Unknown): $\mathbf{U} \quad$ Frequency: -

Relief Elevation $(f t)$ :

Discharge over roadway at $Q_{100}\left(f^{3} / \mathrm{sec}\right)$ :

Are there other structures nearby? (Yes, No, Unknown): Upstream distance (miles): Town: If No or Unknown, type ctrl-n os Highway No. : Structure No. : Year Built:

Clear span (ft): Clear Height (ft): Full Waterway $\left(f t^{2}\right)$ : 
Downstream distance (miles): Town: Year Built:

Highway No. : Structure No. : Structure Type:

Clear span (ft): Clear Height $(f t)$ : Full Waterway $\left(f^{2}\right)$ : -

Comments:

\section{USGS Watershed Data}

Watershed Hydrographic Data

Drainage area $(D A) \stackrel{\mathbf{2 8 . 5 8}}{\mathbf{m i}} \mathrm{mi}^{2}$ Lake/pond/swamp area 0.03 $\mathrm{mi}^{2}$

Watershed storage (ST) 0.1

Bridge site elevation 810 $\%$

Main channel length 9.3 $\mathrm{ft}$

Headwater elevation 2823 $\mathrm{ft}$ $10 \%$ channel length elevation mi

Main channel slope

(S) $110.4 \mathrm{ft} / \mathrm{mi}$

Watershed Precipitation Data

Average site precipitation in Average headwater precipitation in

Maximum 2yr-24hr precipitation event $(124,2)$ in

Average seasonal snowfall (Sn) $\mathrm{ft}$ 


\section{Bridge Plan Data}

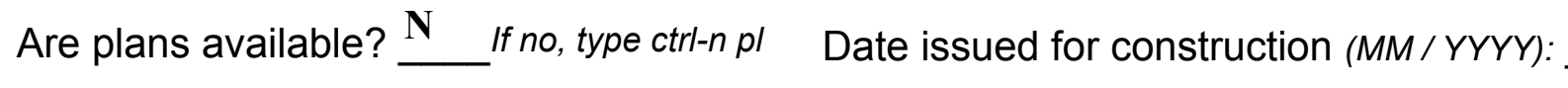

Project Number

Minimum channel bed elevation:

Low superstructure elevation: USLAB DSLAB USRAB DSRAB Benchmark location description:

NO BENCHMARK INFORMATION

Reference Point (MSL, Arbitrary, Other): Datum (NAD27, NAD83, Other):

Foundation Type: 4

If 1 : Footing Thickness

If 2: Pile Type:

If 3: Footing bottom elevation:

Is boring information available? $\mathbf{N}$

Foundation Material Type: $\mathbf{3}$

(1-Spreadfooting; 2-Pile; 3- Gravity; 4-Unknown)

Footing bottom elevation: -

Briefly describe material at foundation bottom elevation or around piles:

NO FOUNDATION MATERIAL INFORMATION 


\section{Cross-sectional Data}

Is cross-sectional data available? $\mathbf{N}$ If no, type ctrl-n xs

Source (FEMA, VTAOT, Other)? -

Comments: NO CROSS SECTION INFORMATION

\begin{tabular}{|l|l|l|l|l|l|l|l|l|l|l|l|}
\hline Station & - & - & - & - & - & - & - & - & - & - & - \\
\hline Feature & - & - & - & - & - & - & - & - & - & - & - \\
\hline $\begin{array}{l}\text { Low chord } \\
\text { elevation }\end{array}$ & - & - & - & - & - & - & - & - & - & - & - \\
\hline $\begin{array}{l}\text { Bed } \\
\text { elevation }\end{array}$ & - & - & - & - & - & - & - & - & - & - & - \\
\hline $\begin{array}{l}\text { Low chord } \\
\text { to bed }\end{array}$ & - & - & - & - & - & - & - & - & - & - & - \\
\hline Station & - & - & - & - & - & - & - & - & - & - & - \\
\hline Feature & - & - & - & - & - & - & - & - & - & - & - \\
\hline $\begin{array}{l}\text { Low chord } \\
\text { elevation }\end{array}$ & - & - & - & - & - & - & - & - & - & - & - \\
\hline $\begin{array}{l}\text { Bed } \\
\text { elevation }\end{array}$ & - & - & - & - & - & - & - & - & - & - & - \\
\hline $\begin{array}{l}\text { Low chord } \\
\text { to bed }\end{array}$ & - & - & - & - & - & - & - & - & - & - & - \\
\hline
\end{tabular}

Source (FEMA, VTAOT, Other)?

Comments: NO CROSS SECTION INFORMATION

\begin{tabular}{|l|l|l|l|l|l|l|l|l|l|l|l|}
\hline Station & - & - & - & - & - & - & - & - & - & - & - \\
\hline Feature & - & - & - & - & - & - & - & - & - & - & - \\
\hline $\begin{array}{l}\text { Low chord } \\
\text { elevation }\end{array}$ & - & - & - & - & - & - & - & - & - & - & - \\
\hline $\begin{array}{l}\text { Bed } \\
\text { elevation }\end{array}$ & - & - & - & - & - & - & - & - & - & - & - \\
\hline $\begin{array}{l}\text { Low chord } \\
\text { to bed }\end{array}$ & - & - & - & - & - & - & - & - & - & - & - \\
\hline Station & - & - & - & - & - & - & - & - & - & - & - \\
\hline Feature & - & - & - & - & - & - & - & - & - & - & - \\
\hline $\begin{array}{l}\text { Low chord } \\
\text { elevation }\end{array}$ & - & - & - & - & - & - & - & - & - & - & - \\
\hline $\begin{array}{l}\text { Bed } \\
\text { levation }\end{array}$ & - & - & - & - & - & - & - & - & - & - & - \\
\hline $\begin{array}{l}\text { Low chord } \\
\text { to bed }\end{array}$ & - & - & - & - & - & - & - & - & - & - & - \\
\hline
\end{tabular}




\section{APPENDIX E: \\ LEVEL I DATA FORM}


U. S. Geological Survey

Bridge Field Data Collection and Processing Form

Qa/Qc Check by: EMB Date: $02 / 06 / 95$

\section{Structure Number}

\section{A. General Location Descriptive}

1. Data collected by (First Initial, Full last name) M. WEBER

2. Highway District Number 04

Date $(M M / D D / Y Y)$

$10 / 20 / 1994$

County ORANGE (017)

Waterway ( $I$ - 6) THIRD BRANCH WHITE RIVER

Route Number TH15

Mile marker 000000

Town BRAINTREE (07600)

Road Name -

Hydrologic Unit Code: $\mathbf{0 1 0 8 0 1 0 5}$

3. Descriptive comments:

The bridge is 0.2 miles from the junction of TH 15 and VT12A. Railroad tracks are parallel to the stream on the right bank.

\section{B. Bridge Deck Observations}
4. Surface cover... LBUS 5
RBUS 5
LBDS 5
RBDS 5
Overall 5

(2b us, ds,lb,rb: 1- Urban; 2- Suburban; 3- Row crops; 4- Pasture; 5- Shrub- and brushland; 6- Forest; 7- Wetland)
5. Ambient water surface... US 1
UB 1
DS 1
(1- pool; 2- riffle)

6. Bridge structure type 1 (1- single span; 2- multiple span; 3- single arch; 4- multiple arch; 5-cylindrical culvert; 6- box culvert; or 7- other)
7. Bridge length 44
(feet)
Span length $\mathbf{3 5}$
(feet)
Bridge width 14.3 (feet)

\section{Road approach to bridge:}
8. LB 1 RB 1
( 0 even, 1- lower, 2- higher)
9. LB 2 RB $\underline{2}$
(1-Paved, 2- Not paved)

10. Embankment slope (run / rise in feet / foot)

US left

US right

\begin{tabular}{|c|c|c|c|}
\hline \multicolumn{2}{|c|}{ Protection } & \multirow{2}{*}{ 13.Erosion } & 14.Severity \\
\cline { 2 - 2 } 11.Type & 12.Cond. & & \\
\hline $\mathbf{1}$ & $\mathbf{1}$ & $\mathbf{0}$ & - \\
\hline
\end{tabular}

LBUS

RBUS

RBDS

LBDS

\begin{tabular}{l|l|l|l}
\hline 1 & 1 & 0 & - \\
\hline 2 & 1 & 2 & 1 \\
\hline 2 & $\frac{1}{1}$ & 0 & - \\
\hline
\end{tabular}

Bank protection types: 0- none; 1- < 12 inches;

2- < 36 inches; 3- < 48 inches;

4- < 60 inches; 5- wall / artificial levee

Bank protection conditions: 1- good; 2- slumped;

3- eroded; 4- failed

Erosion: 0 - none; 1- channel erosion; 2 -

road wash; 3- both; 4- other

Erosion Severity: 0 - none; 1- slight; 2- moderate; 3- severe

\section{Channel approach to bridge (BF):}

15. Angle of approach: $\mathbf{0}$

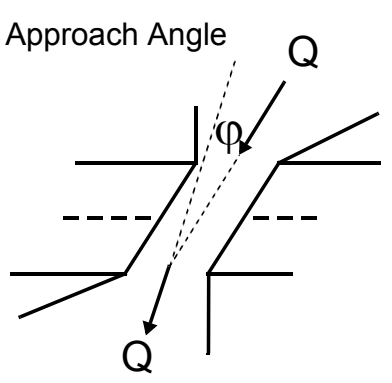

17. Channel impact zone 1:

Where? $(L B, R B)$

Range? feet -

Channel impact zone 2:

Where? $(L B, R B)$

Range? - $\quad$ feet -

(US, UB, DS) to feet Impact Severity: 0- none to very slight; 1-Slight; 2- Moderate; 3- Severe

16. Bridge skew: 25 Bridge Skew Angle

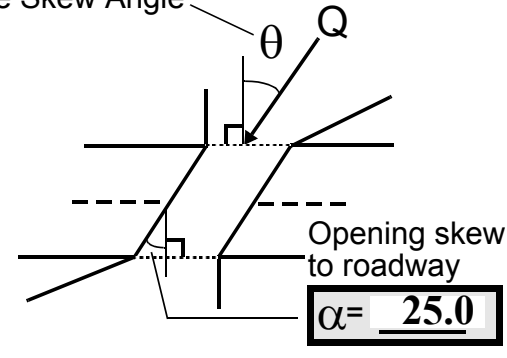

Exist? $\mathbf{N}(Y$ or $N)$

Severity (US, UB, DS) to -

Exist? $\mathbf{N}(Y$ or $N)$

Severity - 
18. Bridge Type: 1a

1a- Vertical abutments with wingwalls

1 b- Vertical abutments without wingwalls

2- Vertical abutments and wingwalls, sloping embankment Wingwalls parallel to abut. face

3- Spill through abutments

4- Sloping embankment, vertical wingwalls and abutments

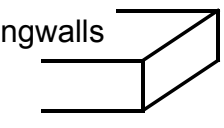

1a with wingwalls

Wingwall angle less than $90^{\circ}$.

19. Bridge Deck Comments (surface cover variations, measured bridge and span lengths, bridge type variations, approach overflow width, etc.)

There are some trees on the right bank upstream but it is not heavily forested. The roadway width is approximately equal to the deck width, however, there are no true embankments, so road overflow will not act as weir flow. The upstream road approach protection is light. The road wash erosion at the right bank upstream road approach is probably off the embankment of nearby VT12A and the railroad embankment.

\section{Upstream Channel Assessment}

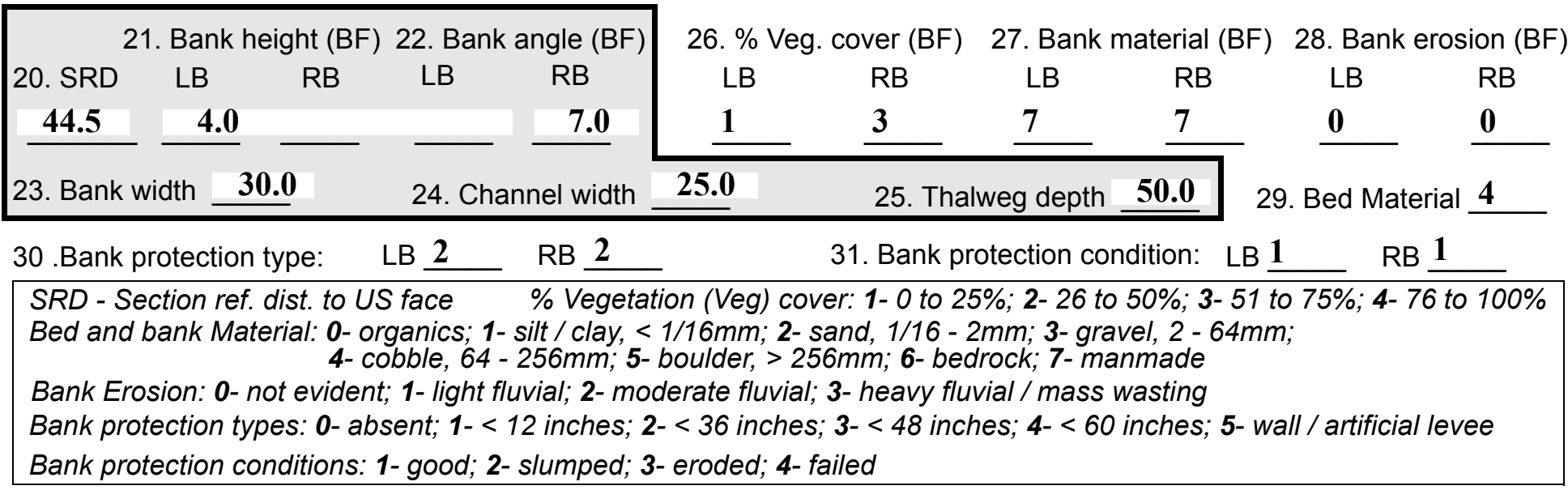

32. Comments (bank material variation, minor inflows, protection extent, etc.):

Unprotected banks further upstream indicate the bank material is fine sand and silt. Both banks have light fluvial erosion. On the streambed, sand is visible between cobbles. The cobbles are of a fairly uniform size and many are flat. There is local anabranching and gravel bars in the streambed several hundred feet upstream, which may have been caused by a $3 \mathrm{ft}$ high beaver dam at about $900 \mathrm{ft}$ upstream. The streambed material under the bridge and in the pooled area upstream is much larger than at the riffle far upstream. The banks near the bridge are well protected with stone fill. There is a small tributary about 500-600 ft upstream entering on the left bank, which is approximately $5 \%$ of the flow in the Third Branch White River. 
33.Point/Side bar present? $\mathbf{N}(Y$ or $N$. if $N$ type ctrl-n pb)34. Mid-bar distance: -

35. Mid-bar width: -

36. Point bar extent: feet (US, UB) to feet (US, UB, DS) positioned $\%$ LB to $\% \mathrm{RB}$

37. Material: -

38. Point or side bar comments (Circle Point or Side; Note additional bars, material variation, status, etc.):

NO POINT BARS

39. Is a cut-bank present? $\underline{\mathbf{N}}$ (Y or if $\mathrm{N}$ type ctrl-n cb)

40. Where? (LB or $R B)$

41. Mid-bank distance: -

42. Cut bank extent: feet (US, UB) to feet (US, UB, DS)

43. Bank damage: (1- eroded and/or creep; 2- slip failure; 3- block failure)

44. Cut bank comments (eg. additional cut banks, protection condition, etc.):

NO CUT-BANKS

\section{Is channel scour present? $\mathbf{Y}$ (Y or if $N$ type ctrl-n cs) 46. Mid-scour distance: $\mathbf{5 0}$}

47. Scour dimensions: Length $\underline{\mathbf{2 6 5}}$ Width $\underline{\mathbf{1 5}}$ Depth : $\underline{\mathbf{1}}$ Position $\underline{\mathbf{1 0}} \%$ LB to $\underline{\mathbf{9 0}} \% \mathrm{RB}$

48. Scour comments (eg. additional scour areas, local scouring process, etc.):

Upstream scour starts at about $100 \mathrm{ft}$ upstream and is about $1 \mathrm{ft}$ deeper than in other pools upstream. More comments are in the downstream channel scour section. The channel scour deepens downstream.

\section{Are there major confluences? $\mathbf{N}$}

51. Confluence 1: Distance Confluence 2: Distance 52. Enters on Enters on 4. Confluence comments (eg. confluence name):

\section{NO MAJOR CONFLUENCES}

NO MAJOR CON
50. How many? -

53. Type(1-perennial; 2- ephemeral)

Type (1- perennial; 2- ephemeral) ( $L B$ or $R B)$ ( $L B$ or $R B)$

\section{Under Bridge Channel Assessment}

55. Channel restraint (BF)? LB 2

\begin{tabular}{|ccccc}
\hline \multicolumn{2}{|c}{56. Height (BF) } & \multicolumn{3}{c}{57 Angle (BF) } \\
LB & RB & LB & RB \\
$\mathbf{2 7 . 5}$ & & & $\mathbf{2 . 5}$ & \\
\hline
\end{tabular}

58. Bank width (BF) (1- natural bank; 2- abutment; 3- artificial levee)

Bed and bank Material: 0- organics; 1- silt / clay, < 1/16mm; 2- sand, 1/16 - 2mm; 3- gravel, 2 - 64mm; 4- cobble, 64 - 256mm; 5- boulder, > 256mm; 6- bedrock; 7- manmade

\begin{tabular}{|c|c|c|c|}
\hline \multicolumn{2}{|c|}{ 61. Material (BF) } & \multicolumn{2}{|c|}{ 62. Erosion (BF) } \\
\hline LB & $\mathrm{RB}$ & LB & $\mathrm{RB}$ \\
\hline 2 & 7 & 7 & 0 \\
\hline
\end{tabular}

60. Thalweg depth $\lcm{90.0}$

63. Bed Material $\mathbf{0}$

Bank Erosion: 0- not evident; 1- light fluvial; 2- moderate fluvial; 3- heavy fluvial / mass wasting

64. Comments (bank material variation, minor inflows, protection extent, etc.):

4

The bed material ranges from sand to boulders, with the median size being large cobble. Some material appears to be stone fill. Low flow is constricted by the abutments. 
65. Debris and Ice Is there debris accumulation?

$(Y$ or $N)$ 66. Where? $\mathbf{N}$

(1- Upstream; 2- At bridge; 3- Both)

67. Debris Potential ( 1- Low; 2- Moderate; 3- High)

68. Capture Efficiency 2

(1-Low; 2- Moderate; 3- High)

69. Is there evidence of ice build-up? 2

Ice Blockage Potential $\mathbf{N}$

(1- Low; 2- Moderate; 3- High)

70. Debris and Ice Comments:

2

There is some debris in the channel downstream possibly due to beavers in the area.

\begin{tabular}{|l|c|c|c|c|c|c|c|c|}
\hline Abutments & $\begin{array}{c}71 . \text { Attack } \\
\angle \text { (BF) }\end{array}$ & $\begin{array}{c}\text { 72. Slope } \angle \\
\text { (Qmax) }\end{array}$ & $\begin{array}{c}\text { 73. Toe } \\
\text { loc. (BF) }\end{array}$ & $\begin{array}{c}\text { 74. Scour } \\
\text { Condition }\end{array}$ & $\begin{array}{c}75 . \text { Scour } \\
\text { depth }\end{array}$ & $\begin{array}{c}\text { 76. Exposure } \\
\text { depth }\end{array}$ & 77. Material & 78. Length \\
\hline LABUT & & - & $\mathbf{9 0}$ & $\mathbf{2}$ & $\mathbf{2}$ & $\mathbf{0}$ & $\mathbf{1}$ & $\mathbf{9 0 . 0}$ \\
\hline RABUT & $\mathbf{1}$ & - & $\mathbf{9 0}$ & & & $\mathbf{2}$ & $\mathbf{2}$ & $\mathbf{3 1 . 0}$ \\
\hline
\end{tabular}

Pushed: $L B$ or RB

Toe Location (Loc.): 0- even, 1- set back, 2- protrudes

Scour cond.: 0- not evident; 1- evident (comment); 2- footing exposed; 3-undermined footing; 4- piling exposed; 5- settled; 6- failed

Materials: 1- Concrete; 2- Stone masonry or drywall; 3- steel or metal; 4- wood

79. Abutment comments (eg. undermined penetration, unusual scour processes, debris, etc.):

0

1

1

The footing exposure of the left abutment is on the downstream end. The right abutment footing is exposed on the upstream end.

80. Wingwalls:

Exist? Material? Scour Scour Exposure Angle? Length? Condition? depth? depth?

USLWW:

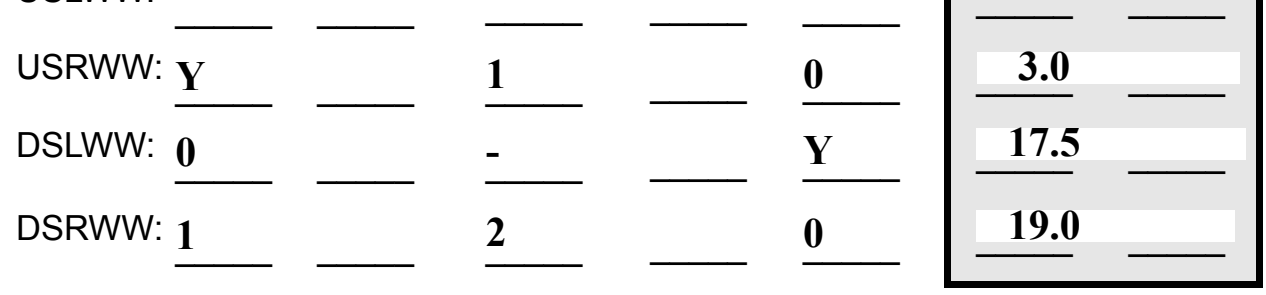

Wingwall materials: 1- Concrete; 2- Stone masonry or drywall; 3- steel or metal; 4- wood

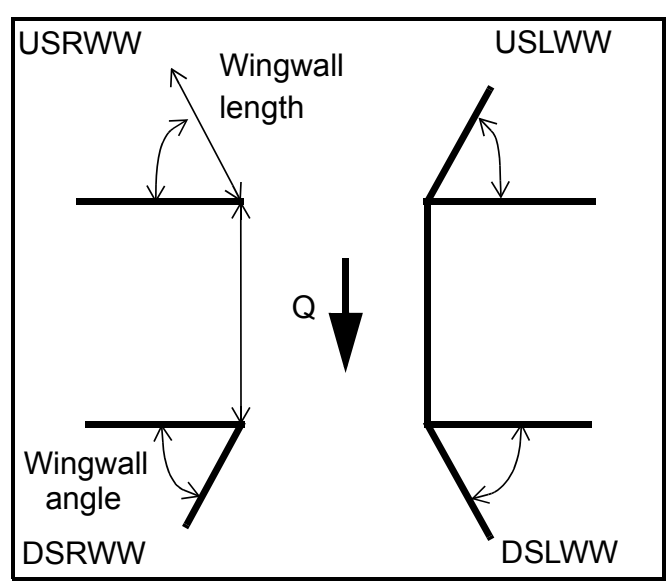

82. Bank / Bridge Protection:

\begin{tabular}{|l|l|l|l|l|l|l|l|l|}
\hline Location & USLWW & USRWW & LABUT & RABUT & LB & RB & DSLWW & DSRWW \\
\hline Type & $\mathbf{0 . 5}$ & $\mathbf{2}$ & $\mathbf{Y}$ & $\mathbf{0}$ & $\mathbf{1}$ & $\mathbf{1}$ & - & - \\
\hline Condition & $\mathbf{Y}$ & $\mathbf{0}$ & $\mathbf{1}$ & - & $\mathbf{1}$ & $\mathbf{2}$ & - & - \\
\hline Extent & $\mathbf{1}$ & $\mathbf{1}$ & $\mathbf{0}$ & $\mathbf{2}$ & $\mathbf{2}$ & $\mathbf{0}$ & $\mathbf{0}$ & - \\
\hline
\end{tabular}

Bank / Bridge protection types: 0- absent; 1- < 12 inches; 2- < 36 inches; 3- < 48 inches; 4- < 60 inches; 
83. Wingwall and protection comments (eg. undermined penetration, unusual scour processes, etc.):

-
-
-
-
-
3
1
3
2
1
1

Piers:

84. Are there piers? On (Y or if $N$ type ctrl-n pr)

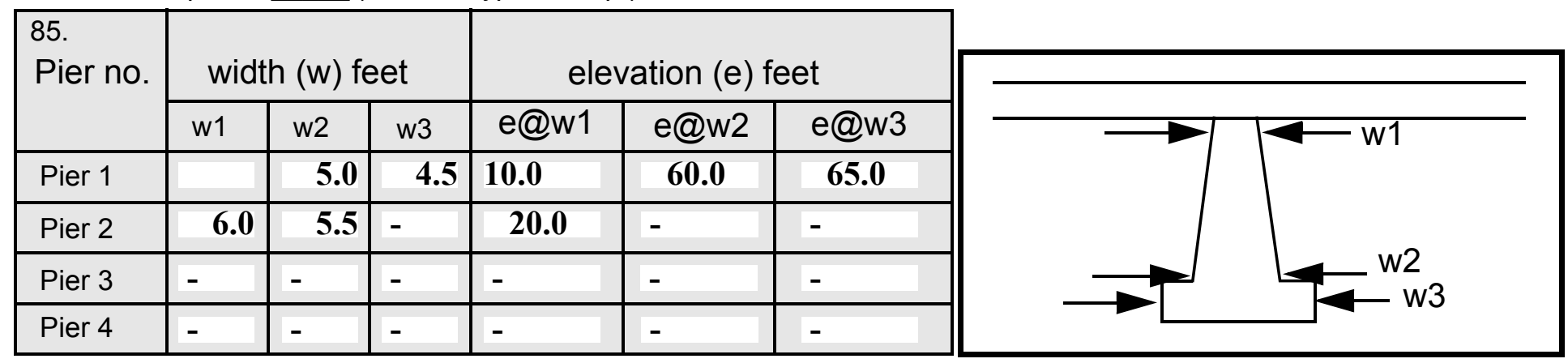

\begin{tabular}{|l|l|l|l|l|}
\hline Level 1 Pier Descr. & \multicolumn{1}{|c|}{1} & \multicolumn{1}{|c|}{2} & \multicolumn{1}{|c|}{3} & \multicolumn{1}{|c|}{ as } \\
\hline 86. Location (BF) & e type- & left & the up- & d \\
\hline 87. Type & $\mathbf{3}$ & wing & strea & well \\
\hline 88. Material & boul- & wall, & m & as \\
\hline 89. Shape & der & cov- & junc- & the \\
\hline 90. Inclined? & is at & er- & tion & foot- \\
\hline 91. Attack $\angle$ (BF) & the & ing & with & ing. \\
\hline 92. Pushed & base & most & the & Ther \\
\hline 93. Length (feet) & - & - & - & - \\
\hline 94. \# of piles & of & of its & left & e is \\
\hline 95. Cross-members & the & base & abut & type- \\
\hline 96. Scour Condition & dow & lengt & ment & $\mathbf{2}$ \\
\hline 97. Scour depth & nstre & h, & is ex- & pro- \\
\hline 98. Exposure depth & am & but & pose & tec- \\
\hline
\end{tabular}

LFP, LTB, LB, MCL, MCM, MCR, RB, RTB, RFP

1- Solid pier, 2- column, 3- bent

1-Wood; 2-concrete; 3- metal; 4- stone

1- Round; 2- Square; 3- Pointed

Y-yes; $N-$ no

$L B$ or $R B$

0- none; 1- laterals; 2- diagonals; 3- both

0- not evident; 1- evident (comment);

2- footing exposed; 3- piling exposed;

4- undermined footing; 5- settled; 6- failed 
99. Pier comments (eg. undermined penetration, protection and protection extent, unusual scour processes, etc.): tion on the left bank downstream.

$\mathbf{N}$

100.

\section{E. Downstream Channel Assessment}

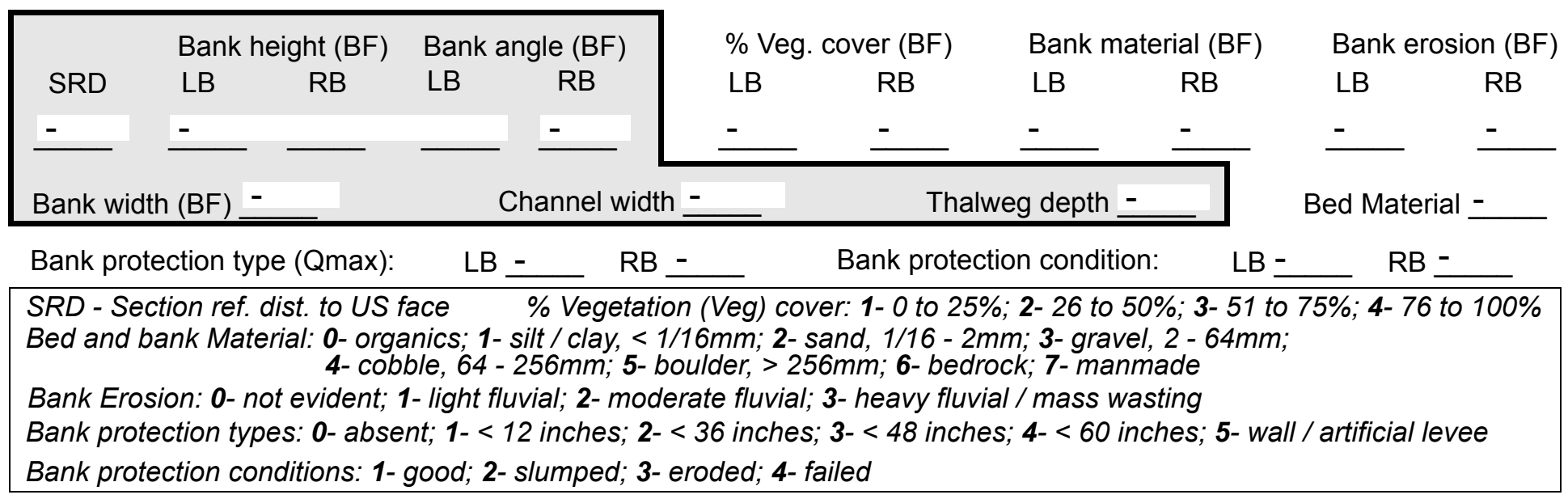

Comments (eg. bank material variation, minor inflows, protection extent, etc.):

-

\section{Is a drop structure present? __ ( $Y$ or $N$, if $N$ type ctrl-n $d s) \quad$ 102. Distance: ___ feet}

103. Drop: __ feet 104. Structure material: ___ (1- steel sheet pile; 2- wood pile; 3- concrete; 4- other)

105. Drop structure comments (eg. downstream scour depth): 
106. Point/Side bar present? (Y or $N$. if $N$ type ctrl-n pb)Mid-bar distance:

Mid-bar width: -

Point bar extent: feet -

(US, UB, DS) to feet (US, UB, DS) positioned $\%$ LB to $\% R B$ Material:

Point or side bar comments (Circle Point or Side; note additional bars, material variation, status, etc.):

$\underline{\text { Is a cut-bank present? }} \mathbf{N}$ (Y or if $N$ type ctrl- $n$ cb) Where? $\underline{\mathbf{O}}$ (LB or RB) Mid-bank distance: $\underline{\text { PIE }}$ Cut bank extent: $\underline{\mathbf{R S}}$ feet __ (US, UB, DS) to feet (US, UB, DS)

Bank damage: (1- eroded and/or creep; 2- slip failure; 3- block failure)

Cut bank comments (eg. additional cut banks, protection condition, etc.):

Is channel scour present? ( $Y$ or if $N$ type ctrl-n cs) Width 2 Depth: 7 Mid-scour distance: 1 Scour dimensions: Length 1

Scour comments (eg. additional scour areas, local scouring process, etc.): 4

0

2

Are there major confluences? 1 (Y or if $N$ type ctrl-n mc) Confluence 1: Distance maEnters on teri- (LB or RB) How many? Bed Confluence 2: Distance large Enters on cob- (LB or RB) Type al is (1-perennial; 2- ephemeral) Type bles, (1- perennial; 2- ephemeral) Confluence comments (eg. confluence name):

small boulders, and sand until $100 \mathrm{ft}$ downstream where it is a sand channel over coarser material until the debris dam. Estimated maximum depth of the pool downstream is $6 \mathrm{ft}$. In the shallow areas, the sand layer is

\section{F. Geomorphic Channel Assessment}

107. Stage of reach evolution onl
1- Constructed

2- Stable

3- Aggraded

4- Degraded

5- Laterally unstable

6- Vertically and laterally unstable 
108. Evolution comments (Channel evolution not considering bridge effects; See HEC-20, Figure 1 for geomorphic descriptors):

y a few inches deep. Sand bank material is exposed at a large cut-bank $700 \mathrm{ft}$ downstream on the left bank. There is also a large point bar at about $700 \mathrm{ft}$ downstream on the right bank. There is no bank erosion within 2 bridge lengths, but where the left bank and right bank are unprotected, the banks are slightly cut. The right bank within 2 bridge lengths is protected with stone fill. The channel width at the exit section is about twice as wide as in the approach or bridge sections. The channel is very deep in areas upstream, under the bridge, and especially downstream. Local anabranching was seen in unprotected reaches far downstream. 


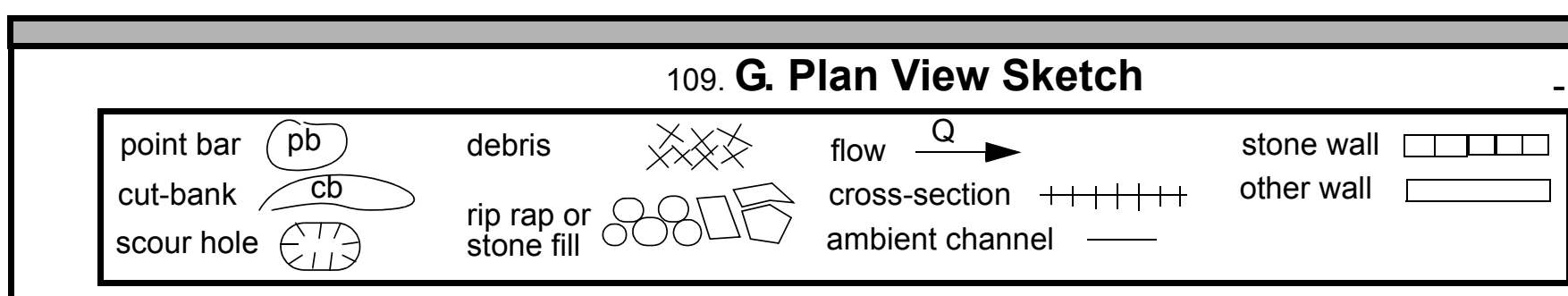


APPENDIX F:

SCOUR COMPUTATIONS 
SCOUR COMPUTATIONS

\begin{tabular}{|c|c|c|c|}
\hline $\begin{array}{ll}\text { Structure Number: } & \text { BRAITH00150013 } \\
\text { Road Number: } & \text { TH } 15\end{array}$ & & $\begin{array}{l}\text { Town: } \\
\text { County: }\end{array}$ & $\begin{array}{l}\text { BRAINTREE } \\
\text { ORANGE }\end{array}$ \\
\hline Stream: $\quad$ 3RD BRANCH WHITE RIVER & & & \\
\hline Initials RLB & Checked: & $\mathrm{ECW}$ & \\
\hline Analysis of contraction scour, live & -bed or $\mathrm{cl}$ & lear wate & \\
\hline $\begin{array}{l}\text { Critical Velocity of Bed Material } \\
\text { VC=11.21*y } 1^{\wedge} 0.1667 * \mathrm{D} 50^{\wedge} 0.33 \text { with Ss } \\
\text { (Richardson and Davis, 1995, p. 28, }\end{array}$ & $\begin{array}{l}\text { Converted } \\
=2.65 \\
\text { eq. } 16)\end{array}$ & to Engli & sh units) \\
\hline Approach Section & & & \\
\hline Characteristic & $100 \mathrm{yr}$ & $500 \mathrm{yr}$ & other $Q$ \\
\hline Total discharge, cfs & 4700 & 5800 & 1450 \\
\hline Main Channel Area, ft2 & 350 & 370 & 223 \\
\hline Left overbank area, ft2 & 1095 & 1290 & 1 \\
\hline Right overbank area, ft2 & 9 & 15 & 0 \\
\hline Top width main channel, ft & 50 & 50 & 46 \\
\hline Top width L overbank, ft & 491 & 491 & 5 \\
\hline Top width $\mathrm{R}$ overbank, ft & 13 & 14 & 0 \\
\hline D50 of channel, ft & 0.2531 & 0.2531 & 0.2531 \\
\hline D50 left overbank, ft & -- & -- & -- \\
\hline D50 right overbank, ft & -- & -- & -- \\
\hline y1, average depth, MC, ft & 7.0 & 7.4 & 4.8 \\
\hline y1, average depth, LOB, ft & 2.2 & 2.6 & 0.2 \\
\hline yl, average depth, ROB, ft & 0.7 & 1.1 & ERR \\
\hline Total conveyance, approach & 111101 & 137728 & 20329 \\
\hline Conveyance, main channel & 40599 & 44529 & 20319 \\
\hline Conveyance, LOB & 70325 & 92833 & 10 \\
\hline Conveyance, ROB & 177 & 367 & 0 \\
\hline Percent discrepancy, conveyance & 0.0000 & -0.0007 & 0.0000 \\
\hline Qm, discharge, MC, Cfs & 1717.5 & 1875.2 & 1449.3 \\
\hline Q1, discharge, LOB, Cfs & 2975.0 & 3909.4 & 0.7 \\
\hline Qr, discharge, ROB, cfs & 7.5 & 15.5 & 0.0 \\
\hline Vm, mean velocity $\mathrm{MC}$, ft/s & 4.9 & 5.1 & 6.5 \\
\hline V1, mean velocity, LOB, ft/s & 2.7 & 3.0 & 0.7 \\
\hline Vr, mean velocity, ROB, ft/s & 0.8 & 1.0 & ERR \\
\hline Vc-m, crit. velocity, $\mathrm{MC}$, ft/s & 9.8 & 9.9 & 9.2 \\
\hline VC-1, crit. velocity, LOB, ft/s & ERR & ERR & ERR \\
\hline Vc-r, crit. velocity, ROB, ft/s & ERR & ERR & ERR \\
\hline Results & & & \\
\hline Live-bed(1) or Clear-Water(0) Contr & action ScC & our? & \\
\hline Main Channel & 0 & 0 & 0 \\
\hline Left Overbank & $\mathrm{N} / \mathrm{A}$ & $\mathrm{N} / \mathrm{A}$ & $\mathrm{N} / \mathrm{A}$ \\
\hline Right Overbank & $\mathrm{N} / \mathrm{A}$ & $\mathrm{N} / \mathrm{A}$ & $\mathrm{N} / \mathrm{A}$ \\
\hline
\end{tabular}


Clear Water Contraction Scour in MAIN CHANNEL

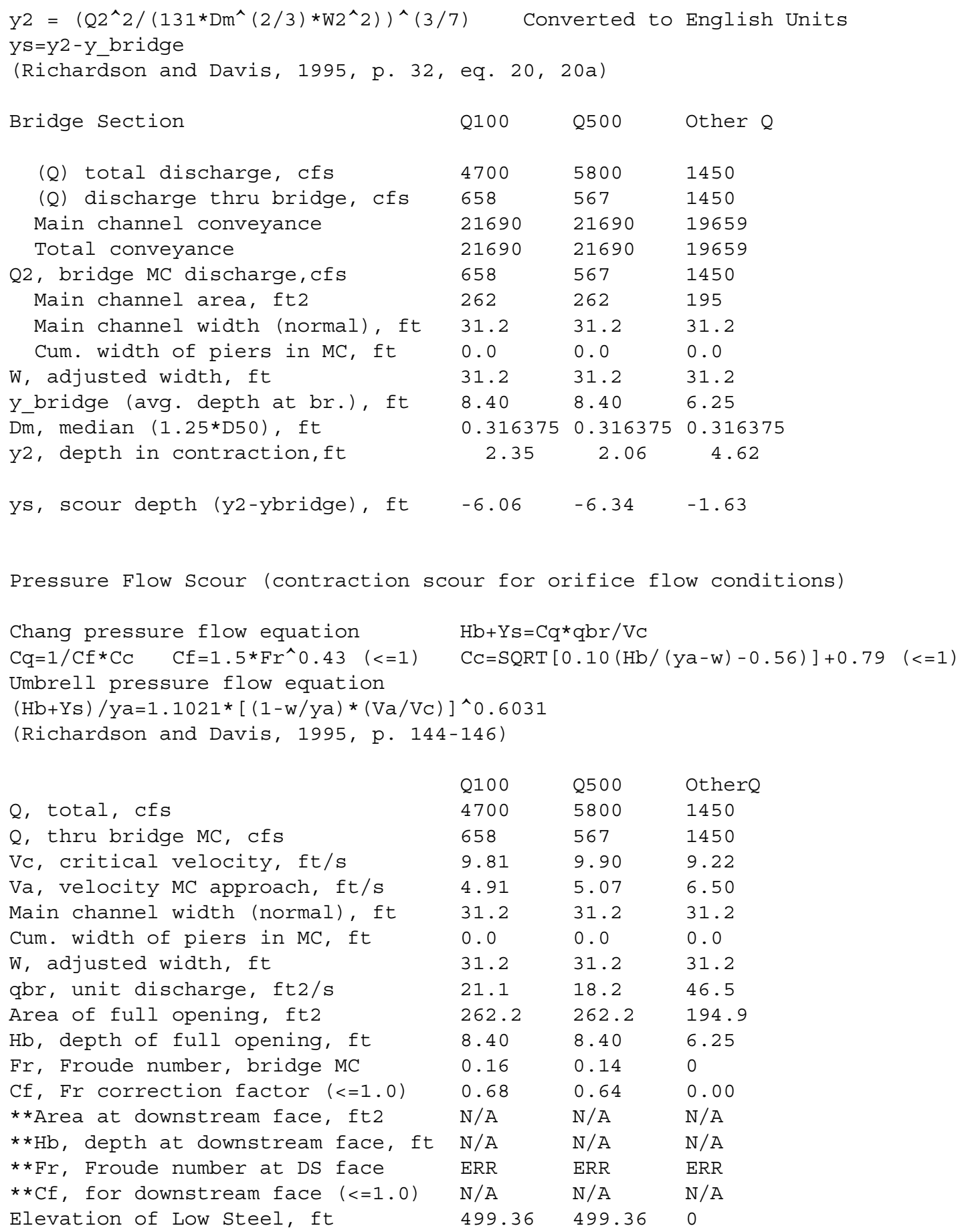




\begin{tabular}{|c|c|c|c|}
\hline Elevation of Bed, ft & 490.96 & 490.96 & -6.25 \\
\hline Elevation of Approach, ft & 500.32 & 500.72 & 0 \\
\hline Friction loss, approach, ft & 0.23 & 0.28 & 0 \\
\hline Elevation of WS immediately US, ft & 500.09 & 500.44 & 0.00 \\
\hline ya, depth immediately US, ft & 9.13 & 9.48 & 6.25 \\
\hline Mean elevation of deck, ft & 501.21 & 501.21 & 0 \\
\hline w, depth of overflow, ft $(>=0)$ & 0.00 & 0.00 & 0.00 \\
\hline Cc, vert contrac correction $(<=1.0)$ & 0.98 & 0.97 & 1.00 \\
\hline$* * \mathrm{CC}$, for downstream face $(<=1.0)$ & ERR & ERR & ERR \\
\hline scour w/Chang equation, ft & -5.19 & -5.47 & $\mathrm{~N} / \mathrm{A}$ \\
\hline Ys, scour w/Umbrell equation, ft & -1.77 & -1.42 & $\mathrm{~N} / \mathrm{A}$ \\
\hline
\end{tabular}

Armoring

\begin{tabular}{|c|c|c|c|}
\hline \multicolumn{4}{|l|}{ 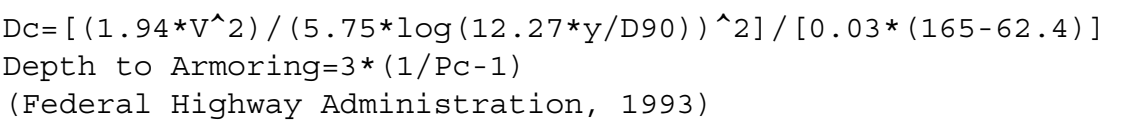 } \\
\hline Downstream bridge face property & $100-y r$ & $500-y r$ & Other \\
\hline Q, discharge thru bridge $M C$, cfs & 658 & 567 & 1450 \\
\hline Main channel area (DS), ft2 & 262.2 & 262.2 & 194.9 \\
\hline Main channel width (normal), ft & 31.2 & 31.2 & 31.2 \\
\hline Cum. width of piers, ft & 0.0 & 0.0 & 0.0 \\
\hline Adj. main channel width, ft & 31.2 & 31.2 & 31.2 \\
\hline D90, ft & 0.5045 & 0.5045 & 0.5045 \\
\hline D95, ft & 0.5613 & 0.5613 & 0.5613 \\
\hline Dc, critical grain size, ft & 0.0225 & 0.0167 & 0.2217 \\
\hline PC, Decimal percent coarser than DC & 1.000 & 1.000 & 0.582 \\
\hline epth & 0.00 & 0.00 & 0.48 \\
\hline
\end{tabular}

Abutment Scour

Froehlich's Abutment Scour

$\mathrm{Ys} / \mathrm{Y} 1=2.27 * \mathrm{~K} 1 * \mathrm{~K} 2 *\left(\mathrm{a}^{\prime} / \mathrm{Y} 1\right)^{\wedge} 0.43 * \mathrm{Fr} 1^{\wedge} 0.61+1$

(Richardson and Davis, 1995, p. 48, eq. 28)

Characteristic

Left Abutment

Right Abutment

$100 \mathrm{yr} Q 500 \mathrm{yr} Q$ Other Q $100 \mathrm{yr} \mathrm{Q} 500 \mathrm{yr} \mathrm{Q}$ Other Q

(Qt), total discharge, Cfs $\quad 4700 \quad 5800 \quad 1450 \quad 4700 \quad 5800$

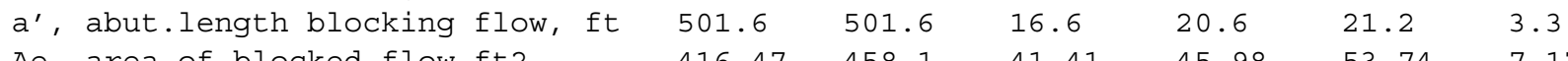

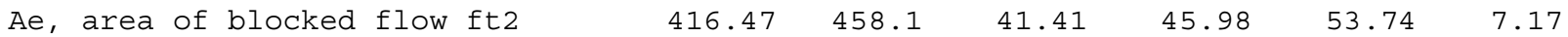

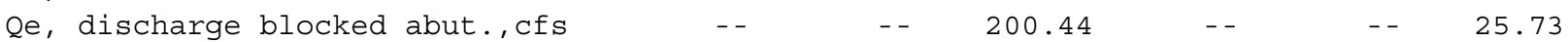

(If using Qtotal_overbank to obtain Ve, leave Qe blank and enter Ve and Fr manually)

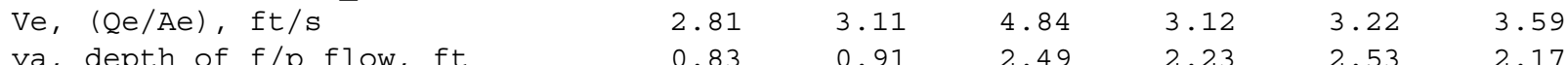

ya, depth of f/p flow, ft $\quad \begin{array}{llllll}0.83 & 0.91 & 2.49 & 2.23 & 2.53 & 2.17\end{array}$

--Coeff., K1, for abut. type (1.0, verti.; 0.82, verti. w/ wingwall; 0.55, spillthru)

$\begin{array}{llllllll}\text { K1 } & 0.82 & 0.82 & 0.82 & 0.82 & 0.82 & 0.82\end{array}$

--Angle (theta) of embankment (<90 if abut. points DS; >90 if abut. points US) 


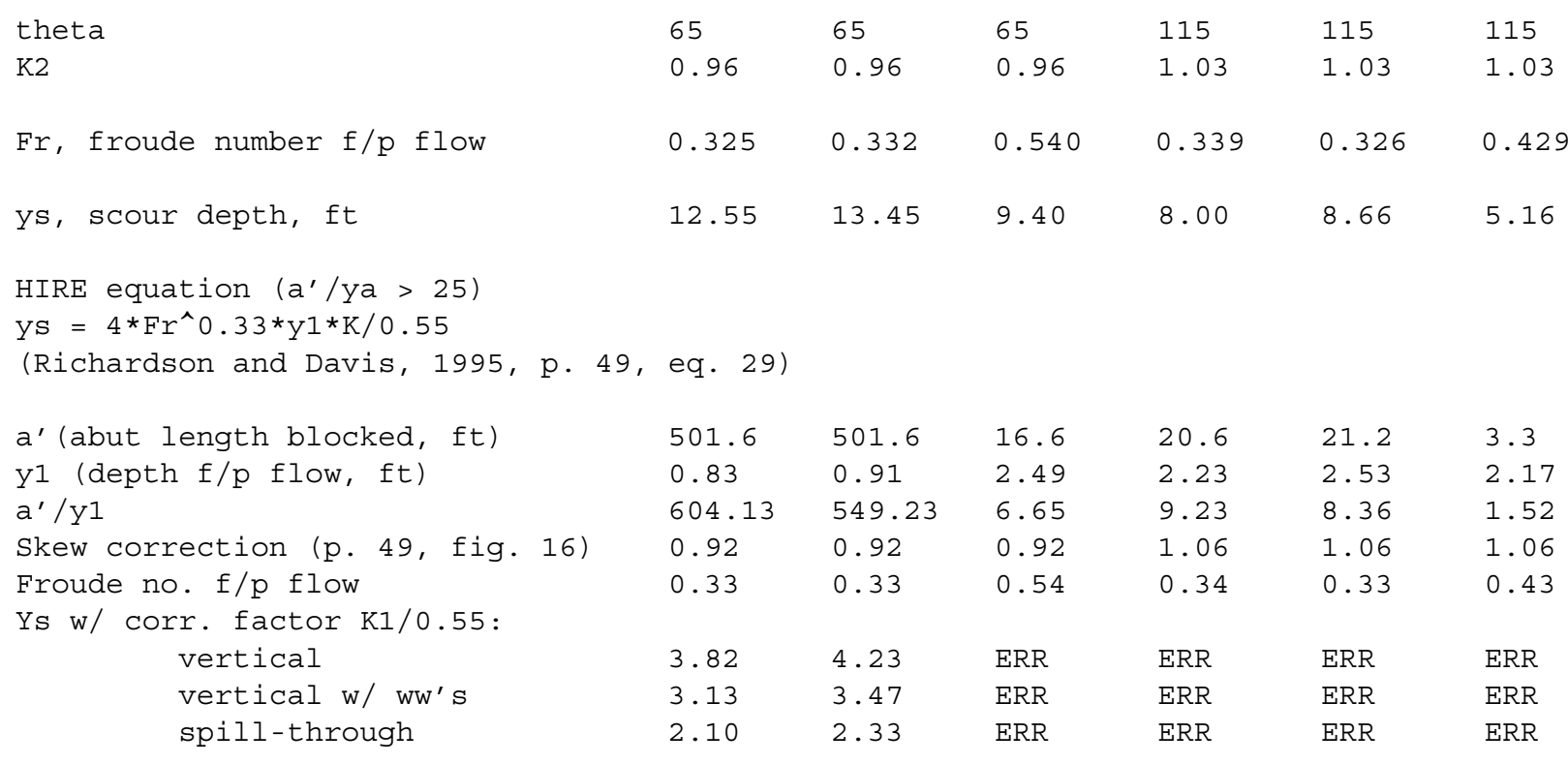

Abutment riprap sizing

Isbash Relationship

$\mathrm{D} 50=\mathrm{Y} * \mathrm{~K} * \mathrm{Fr} \wedge 2 /(\mathrm{Ss}-1)$ and $\mathrm{D} 50=\mathrm{Y} * \mathrm{~K} *\left(\mathrm{Fr} r^{\wedge} 2\right)^{\wedge} 0.14 /(\mathrm{Ss}-1)$

(Richardson and Davis, 1995, p112, eq. 81,82)

\begin{tabular}{|c|c|c|c|c|c|c|}
\hline Characteristic & Q100 & Q500 & Other $\mathrm{Q}$ & Q100 & Q500 & Other Q \\
\hline Fr, Froude Number & 0.16 & 0.14 & 0.52 & 0.16 & 0.14 & 0.52 \\
\hline$y$, depth of flow in bridge, ft & 8.40 & 8.40 & 6.25 & 8.40 & 8.40 & 6.25 \\
\hline Median stone Diameter for ripra & $\therefore$ left & outment & & right & abutment & ft \\
\hline Fr<=0.8 (vertical abut.) & 0.13 & 0.10 & 1.04 & 0.13 & 0.10 & 1.04 \\
\hline Fr>0.8 (vertical abut.) & ERR & ERR & ERR & ERR & ERR & ERR \\
\hline
\end{tabular}


